\title{
Warming world, changing ocean: mitigation and adaptation to support resilient marine systems
}

\author{
Rowan Trebilco $(\mathbb{D} \cdot$ Aysha Fleming $\mathbb{D} \cdot$ Alistair J. Hobday $(\mathbb{D} \cdot$ Jess Melbourne-Thomas $(\mathbb{D} \cdot$ \\ Amelie Meyer (D) J Jan McDonald (D) Phillipa C. McCormack (D)

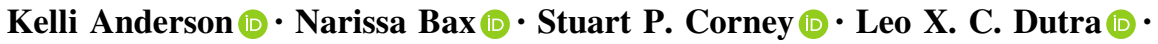 \\ Hannah E. Fogarty $(\mathbb{D} \cdot$ Jeffrey McGee $(\mathbb{D} \cdot$ Kaisu Mustonen - Tero Mustonen $(\mathbb{D} \cdot$ \\ Kimberley A. Norris $(1) \cdot$ Emily Ogier $(\mathbb{D}) \cdot$ Andrew J. Constable $(1) \cdot$ \\ Gretta T. Pecl
}

Received: 20 April 2020/Accepted: 26 July 2021 / Published online: 21 September 2021

(C) Crown 2021

\begin{abstract}
Proactive and coordinated action to mitigate and adapt to climate change will be essential for achieving the healthy, resilient, safe, sustainably harvested and biodiverse ocean that the UN Decade of Ocean Science and sustainable development goals (SDGs) seek. Ocean-based mitigation actions could contribute $12 \%$ of the emissions reductions required by 2030 to keep warming to less than $1.5^{\circ} \mathrm{C}$ but, because substantial warming is already locked in, extensive adaptation action is also needed. Here, as
\end{abstract}

Aysha Fleming, Alistair J. Hobday, Jess Melbourne-Thomas, Amelie Meyer, Jan McDonald and Phillipa C. McCormack contributed equally.

Supplementary Information The online version contains supplementary material available at https://doi.org/10.1007/ s11160-021-09678-4.

R. Trebilco $(\bowtie) \cdot$ A. J. Hobday · J. Melbourne-Thomas CSIRO Oceans \& Atmosphere, Hobart,

TAS, Australia

e-mail: rowan.trebilco@csiro.au

R. Trebilco · A. Fleming · A. J. Hobday ·

J. Melbourne-Thomas - J. McDonald .

P. C. McCormack · N. Bax - S. P. Corney ·

L. X. C. Dutra · H. E. Fogarty · J. McGee .

E. Ogier · A. J. Constable · G. T. Pecl

Centre for Marine Socioecology, University of Tasmania,

Hobart, Australia

A. Fleming

CSIRO Land \& Water, Hobart, TAS, Australia part of the Future Seas project, we use a "foresighting/ hindcasting" technique to describe two scenarios for 2030 in the context of climate change mitigation and adaptation for ocean systems. The "business-asusual" future is expected if current trends continue, while an alternative future could be realised if society were to effectively use available data and knowledge to push as far as possible towards achieving the UN SDGs. We identify three drivers that differentiate between these alternative futures: (i) appetite for climate action, (ii) handling extreme events, and (iii) climate interventions. Actions that could navigate towards the optimistic, sustainable and technically achievable future include:

A. Meyer - K. Anderson - N. Bax ·

S. P. Corney · H. E. Fogarty · J. McGee .

E. Ogier - G. T. Pecl

Institute for Marine and Antarctic Studies, University of Tasmania, Hobart, Australia

A. Meyer

ARC Centre of Excellence for Climate Extremes, Hobart,

Australia

J. McDonald · P. C. McCormack · J. McGee

Faculty of Law, University of Tasmania, Hobart,

Australia

L. X. C. Dutra

CSIRO Oceans \& Atmosphere, Brisbane, Australia 
(i) proactive creation and enhancement of economic incentives for mitigation and adaptation;

(ii) supporting the proliferation of local initiatives to spur a global transformation;

(iii) enhancing proactive coastal adaptation management;

(iv) investing in research to support adaptation to emerging risks;

(v) deploying marine-based renewable energy;

(vi) deploying marine-based negative emissions technologies;

(vii) developing and assessing solar radiation management approaches; and

(viii) deploying appropriate solar radiation management approaches to help safeguard critical ecosystems.

Keywords Blue growth - Global change .

Transdisciplinary $\cdot$ Decade of the ocean $\cdot$ UN sustainable development goals

\section{Introduction}

The world is undergoing a period of unprecedented warming (Cheng et al. 2019) which has been characterised as a climate emergency (Ripple et al. 2019). A critical decade now lies ahead to adapt human and natural systems and to act to keep ongoing warming below catastrophic levels (Hobday and Cvitanovic 2017; Cvitanovic et al. 2018; IOC, UNESCO 2019; Ryabinin et al. 2019). Current global trends in greenhouse gas emissions will lead to at least $1.5^{\circ} \mathrm{C}$ of atmospheric warming by 2030-2050 (relative to preindustrial) and at least $3{ }^{\circ} \mathrm{C}$ by 2100 (Rogelj et al. 2015; IPCC 2019), and half the world's population already experiences temperatures $1.5{ }^{\circ} \mathrm{C}$ warmer than preindustrial (Brierley et al. 2019).This level of

L. X. C. Dutra

Blue Economy CRC-Co Ltd, Newnham, Australia

K. Mustonen · T. Mustonen

Snowchange Cooperative, FIN 81235 Selkie, Finland

K. A. Norris

School of Psychological Sciences, University of

Tasmania, Hobart, Australia climate change is currently having and will continue to have ongoing significant impacts on the ocean, marine ecosystems and reliant socio-ecological systems (Bindoff et al. 2019). These changes and associated impacts are very likely to be outside the range of variability under which modern society and ecosystems have developed and therefore actual impacts are still not fully understood.

The warmest ocean ever was recorded in 2019, beating 2018, which in turn exceeded the previous record year, 2017 (in terms of total heat content; Cheng et al. 2020). Extreme climate-driven events, such as droughts, extreme rainfall, floods, and atmospheric and marine heatwaves are predicted to become more frequent and severe (Oliver et al. 2019), and in many locations increased severity and frequency of extremes is already evident (Cai et al. 2015; O'Gorman 2015; Oliver et al. 2017, 2018). These changes in the physical environment will in turn lead to changes in the distribution, abundance and dynamics of marine life (Melbourne-Thomas et al. 2021; Ward et al. 2020; Pecl et al. 2017, 2019b and see www.redmap.org.au), emergence of new habitats (e.g. coral reefs extending polewards in Japanese waters; Kumagai et al. 2018) and disruption and/or decline of iconic habitat-forming species and ecosystems, such as kelp (ArafehDalmau et al. 2019), coral reefs (Hughes et al. 2017) and mangroves (Bergstrom et al. 2021; Magnan et al. 2019) in their current locations.

Mitigation (i.e. reducing greenhouse gas emissions; see glossary in Table 1) is the frontline response and underpins a precautionary approach. Ocean-based mitigation actions have the capacity to contribute $12 \%$ of the emissions reductions required by 2030 to keep global average warming to less than $1.5{ }^{\circ} \mathrm{C}$ (Hoegh-Guldberg et al. 2019). In addition to reducing greenhouse gas emissions, activities that aim to reduce accumulation of heat in the atmosphere (either by removing greenhouse gases or by increasing the proportion of solar radiation that is reflected rather than absorbed) are gaining increasing attention (McGee et al. 2018; GESAMP 2019) and are implicit in keeping warming below $1.5^{\circ} \mathrm{C}$. Even with radical reduction in greenhouse gas emissions, many proximate effects of warming are unavoidable (Fig. 1, top row).

The nature, scope and scale of current and future 'locked in' climate change impacts will be extensive and mean that the human and biological/ 
Table 1 Glossary of key terms

We follow the IPCC's definition of adaptation as "the process of adjustment to actual or expected climate
adaptation
and its effects. In human systems, adaptation seeks to moderate or avoid harm or exploit beneficial
and its effects" (IPCC 2014).
Adaptation includes both autonomous adaptation (by industry and non-governmental groups) and planned
adaptation (by governments, in which governance instruments and actions support or mandate
adaptation).
Activities that remove greenhouse gasses from the atmosphere, including through afforestation and
reforestation (mangrove and sea grass restoration and kelp farming in the marine context), bioenergy with
carbon capture and storage, iron fertilisation, direct air carbon capture and storage and advanced mineral
weathering.
Biophysical occurrences that have been statically rare/unusual during recorded human history (i.e. over the
past several thousand years) and that have significant ecological and socioeconomic impacts, outside
removal
normal variability. While rarity of occurrence is often part of the definition of extreme events, we use the
term to encompass high-impact events that may occur with increasing frequency and intensity under
climate change.
We follow the IPCC's definition of mitigation: "a human intervention to reduce the sources or enhance the
sinks of greenhouse gases" (IPCC 2014).
Activities that reduce the accumulation of heat in the atmosphere by increasing the proportion of solar
radiation that is reflected rather than absorbed. Solar radiation management activities include the
stratospheric injection of sulphate aerosols and marine cloud brightening.
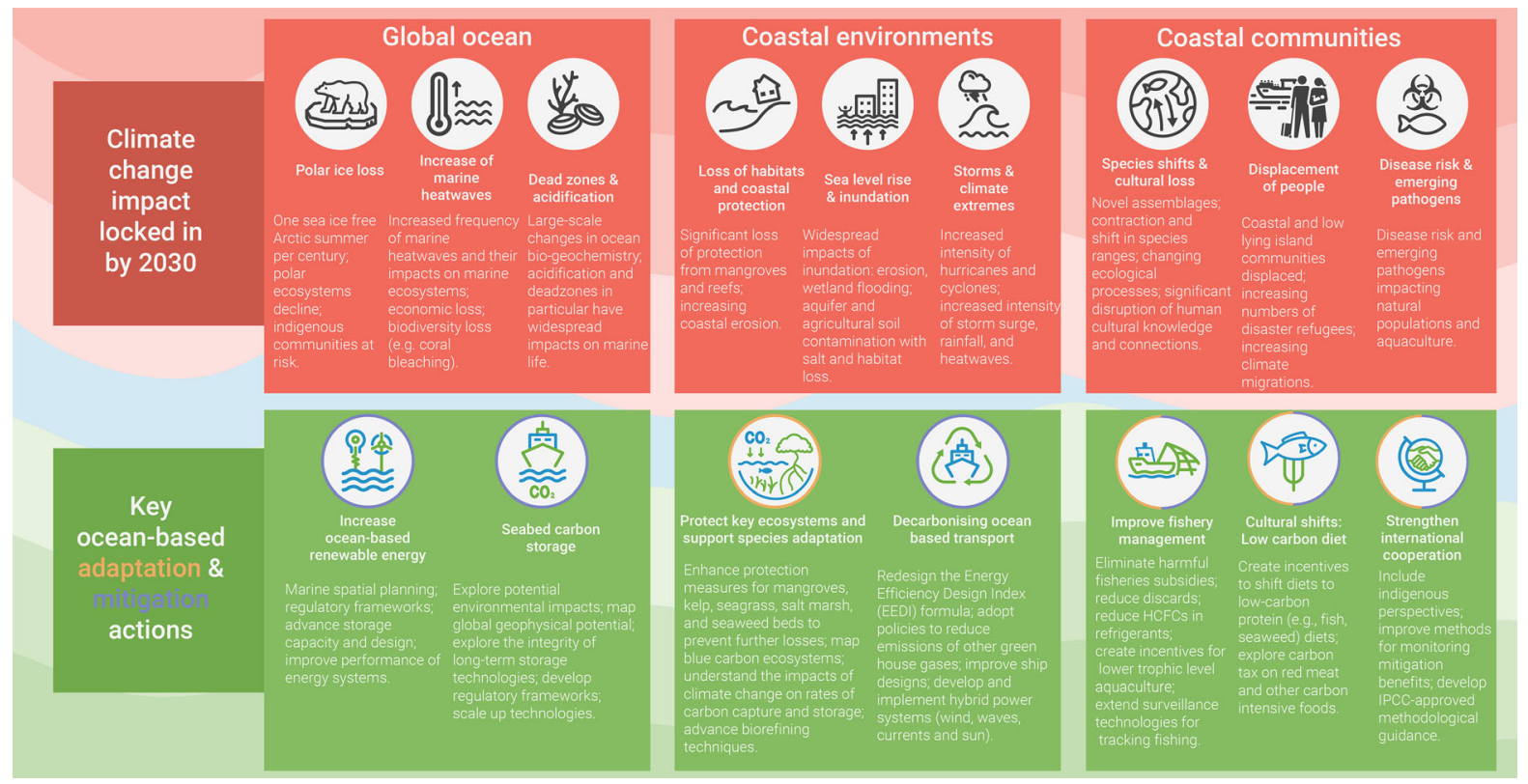

Fig. 1 Climate change impacts 'locked in' for 2030 (IPCC 2014, 2019) and key ocean-based adaptation and mitigation actions (colour coding of icon outlines in bottom panel indicates

ecological responses required to minimise ecological and societal repercussions will also be outside the bounds of previous human experience (Díaz et al. 2019). Adaptation interventions (i.e. those actions whether actions primarily comprise of adaptation [gold] or mitigation [purple] activities, or may include both)

specifically aiming to minimise impacts of 'locked in' change; see glossary in Table 1) can nonetheless be effective in reducing realised impacts (Gattuso et al. 2018). These adaptation interventions focus on 
proximate impact pathways, reducing exposure and sensitivity to impact drivers, and/or on building adaptive capacity (Fig. 2; Creighton et al. 2016; Ogier et al. 2020).

In addition to adaptation interventions, mitigation interventions will be essential to dampen the overall degree of climate change and higher-level impact pathways (Fig. 1; Gattuso et al. 2018; Hoegh-Guldberg et al. 2019), and in doing so, reducing the overall level of required adaptation in the medium to longterm (Fig. 2). The novel scope and scale of required responses means that there is also considerable uncertainty and risk associated with unintended consequences of responses (Howard et al. 2017; Reif and Osberghaus 2020). While decisive action is essential (IPCC 2019; Melbourne-Thomas et al. 2019), success will be contingent upon social processes and governance systems that facilitate proactive and adaptive responses in ways that reduces risks and costs and enhances benefits (Gattuso et al. 2018; Williams et al. 2019). Success will also be contingent on coordinating across autonomous (e.g. industry and non-governmental adaptation) and planned adaptation responses (see Howard and Pecl 2019 and Pecl et al. 2019a).

Substantial work on the likely impacts of climate change upon the ocean and related ecological and human systems has been undertaken to date and synthesised in the IPCC reports (Pachauri et al. 2015;
Bindoff et al. 2019; IPCC 2019). While considerable research has focused on developing adaptation strategies (Hinkel et al. 2013; Wylie et al. 2016), little of this has been on implementing or strengthening those strategies with regard to competing or complementary actions (Williams et al. 2019), or on assessing the suitable mix of adaptation and mitigation actions.

In this paper, we build upon this previous work by using a foresighting scenario analysis technique to envision two alternative possible futures for society and global systems by 2030, in the context of the challenge of climate change adaptation and mitigation. The 2030 time horizon aligns with evidence that the next ten years are a 'critical' decade for action on climate change. The 2030 timeframe is also useful as it means that our analyses can inform priorities for the UN Decade of Ocean Science for Sustainable Development (2021-2030; IOC, UNESCO 2019; Ryabinin et al. 2019) and also represents a time-frame in which local communities feel a strong sense of stewardship and are empowered to act to prepare for future changes (Walter and Hamilton 2014; Jupiter et al 2017). The UN Decade of Ocean Science aims to "support efforts to reverse the cycle of decline in ocean health and gather ocean stakeholders worldwide behind a common framework that will ensure ocean science can fully support countries in creating improved conditions for sustainable development of the Ocean", and
Fig. 2 Mitigation (blue) and adaptation (gold) and interventions to address the impacts of climate change. Interventions with a technological focus (often collectively termed "geoengineering") are shown in green

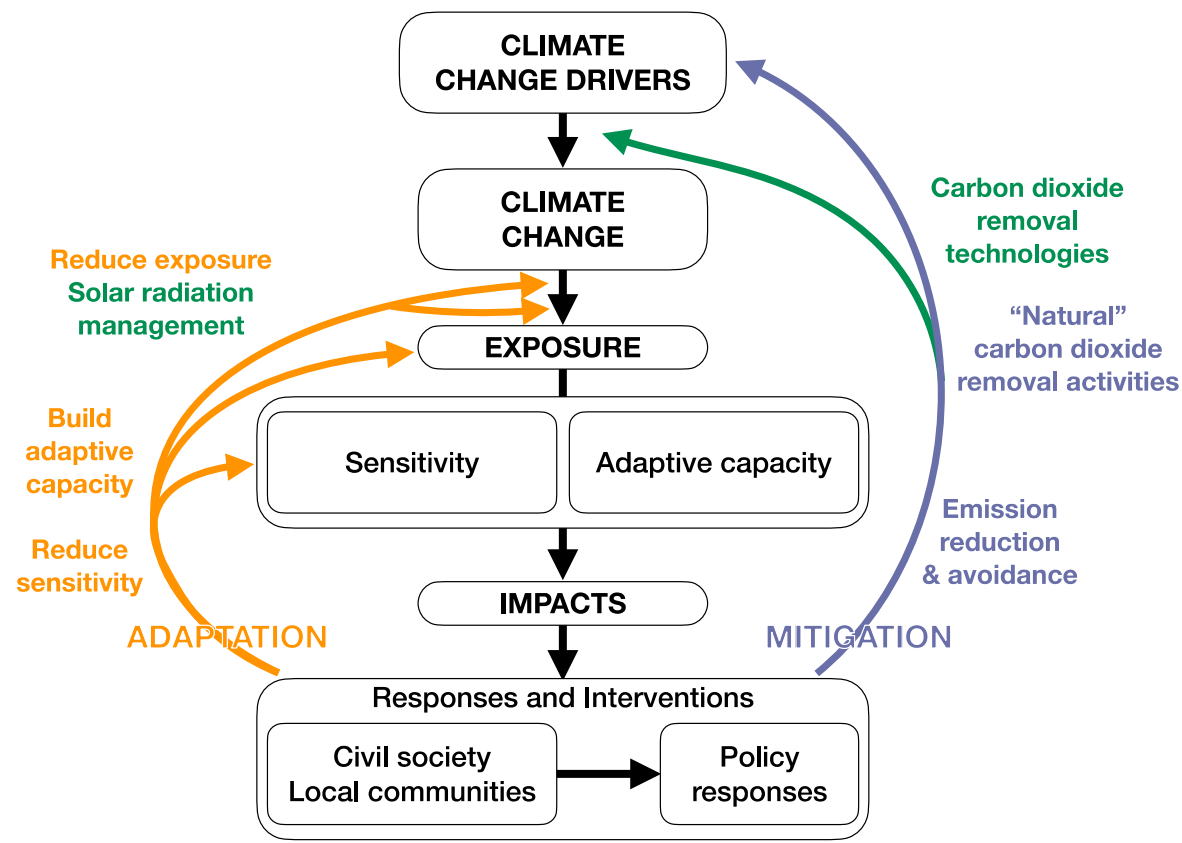


recognises that adaptation strategies and the implementation of science-informed policy responses to global change are urgently needed (IOC, UNESCO 2017,2019).

Scenario analysis has been chosen as the focal method for this paper due to the high levels of uncertainty and complexity inherent in marine socioecological systems (McDonald et al. 2019b). The first scenario is the "business-as-usual" scenario (Nash et al. 2021). It is important to note that this businessas-usual scenario is not necessarily a "worst case"and does not assume there will be no increase in adaptation and mitigation efforts. Instead, the business-as-usual scenario assumes that current trends will continue - in terms of both the rate of adaptation and mitigation action and the behaviour of actors (individuals, civil society, corporations, national governments and others).

The second future is the aspirational, optimistic, but also technically achievable "sustainable" scenario that could be realised if currently-available data and knowledge were used to push as far as possible towards achieving the UN Sustainable Development Goals (SDGs; Norström et al. 2014; United Nations 2015; see Nash et al. 2021 for additional context). The SDGs are used as guideposts for this sustainable future, acknowledging that this still entails unavoidable value judgements and trade-offs within and between goals (Nash et al. 2020; Nilsson et al. 2016). In this optimistic, sustainable scenario both effort and behaviour of actors is most in line with what is needed to achieve SDGs. The additional value of the sustainable scenario is to move beyond usual impact projections to explore the governance and/or policy choices that might be made at various scales (i.e. international, national, sub-national/regional) to arrive at a more desirable future for the ocean (i.e. one more closely aligned with the UN SDGs) in the context of rapidly changing climate. The sustainable scenario is designed to highlight and create the vision of what is technically achievable if society "chooses" to work collaboratively towards the best outcome technically possible. While $2021-2030$ is a critical decade in which decisive mitigation action is essential in order to avoid dangerous levels of warming (IPCC 2014; IPCC 2019; WMO 2019), we recognise that mitigation actions are unlikely to have substantial discernible effects by 2030. In addition to underscoring the importance of mitigation, we also aim to highlight adaptation related interventions, that may also contribute to delivering the SDGs, aiming to position the ocean for the best possible future post2030 .

\section{Methods}

We used the approaches described in Nash et al. (2021) to consider key assumptions, develop scenarios and identify pathways to alternative futures for the ocean given the challenge of climate change adaptation and mitigation. This approach was an iterative forecasting-hindcasting process (Fig. 2) involving expert elicitation and consultation through a series of workshops and meetings. The process included the interdisciplinary author team, which comprises psychology, anthropology, law, governance, management, oceanography, ecology, socioecology, climate science and economics experts, and traditional knowledge leadership (see Figure S1) and with research experience spanning 38 countries (see table S1). The team also consulted with an international group of Traditional Owners and Indigenous knowledge holders, and community representatives (see the preface to this special issue and Fischer et al. 2020 for more details). Throughout the process described below, iteration over the course of several workshops and active engagement of the full author team in workshop discussions and writing helped avoid potential problems arising from linguistic uncertainty, conceptual uncertainty and other uncertainties associated with interdisciplinary collaboration (Carey and Burgman 2008; Freeth and Caniglia 2020).

Specifically, we first identified the scope of the challenge (as outlined above in the introduction) and evaluated how the key assumptions underlying scenario development for 2030 ocean futures, as articulated by Nash et al. (2020) were relevant in the context of climate change adaptation and mitigation. These key assumptions described by Nash et al. (2020) are that: human populations will continue to increase; the globe is locked into a certain degree of warming; no new major international agreements will be commenced; no emergence of new large-scale conflicts; resource use patterns will continue; and knowledge production will continue.

Next we brainstormed to identify drivers of change (i.e. key factors with potential to impact 
capacity for adaptation and mitigation in the ocean in the context of the SDGs, over the next decade) and then arranged them into natural groupings and used expert judgement in an expert setting to distil a set of umbrella drivers (Image S1, Table S2). These umbrella drivers represent 'axes', where the direction of action along each of the axes differentiates between a "business-as-usual" vs. "sustainable but technically achievable" 2030 future, aligned with the SDGs, in the specific context of climate adaptation and mitigation. We next considered the status of the drivers today relative to the two possible futures (Table S2) and developed evidence-based narratives for each future as a basis for the descriptions presented here. These narratives subsequently provided a basis for a 'backcasting' process (Robinson 1990; Nash et al. 2020) in which we developed a set of actions related to each driver that, together, could underpin a pathway to move away from the business-as-usual trajectory to the more desirable/optimistic sustainable future. For each of these actions we considered risks of costs arising and potential benefits (Table S3), as well as how, when and at what spatial scale they would need to be enacted to realise the more sustainable 2030 future. As described in Nash et al 2021, we focused on two contrasting alternative futures (rather than a more exhaustive set of possible scenarios) because this approach allowed us to leverage the vast global effort already employed in defining the SDGs by providing an internationally agreed direction for our detailed action pathways.

In addition to the methods described above, the coauthors on our paper who were members of the Future Seas Indigenous and Traditional Working Group engaged in scenario development (like all members of our author team) and also facilitated a dialogue with all the members of the Indigenous and Traditional Working Group (http://futureseas2030.org/our-team/) to ensure that key messages relevant to First Nations Peoples and marine climate change mitigation and adaptation were included (see Table 2, and Fischer et al. 2020).

\section{Drivers that distinguish pathways to alternative futures}

We identified three overarching high-impact, highinfluence "umbrella" drivers of human responses for the challenge of climate change adaptation and mitigation for the ocean: (i) extreme events; (ii) interventions; and (iii) appetite for climate action. As noted above, these drivers represent key axes that differentiate between the alternate futures, in the specific context of climate change adaptation and mitigation for the oceans. These umbrella drivers are closely related and linked to one another as explained below (Fig. 3).

Here, we consider extreme events as biophysical occurrences that have been statistically rare/unusual during recorded human history (i.e. over the past several thousand years) and that have significant ecological and socioeconomic impacts, outside normal variability (Smith 2011). These are occurrences far from the mean state (Harrington et al. 2019; Bellprat et al. 2019), and in the ocean context they include events such as coastal storms, extreme rainfall, storm surges, coastal flooding events, typhoons, hurricanes, marine heatwaves, anoxic events, and upwelling of acidified water as well as outbreaks of harmful algal blooms and other pathogens and diseases (including the emergence of new pathogens and diseases, Coffey et al. 2019). These extreme events often bring sudden and dramatic impacts for marine ecosystems, coastal communities and infrastructure (Marshall et al. 2013). Although it is difficult to predict the exact timing of such events, in many parts of the world their frequency and intensity is expected to increase substantially in coming decades (Oliver et al. 2019). For example, many of Australia's coastal cities can expect to experience what was previously a once-in-a-century extreme coastal flooding event at least every year by 2050, and more intense tropical cyclones (CSIRO and Bureau of Meteorology, Australia 2015; Webb and Hennessey 2015).

In the context of the challenge of climate change adaptation and mitigation, the business- as-usual vs. sustainable alternative futures are largely differentiated by the way that these extreme events are handled. Business-as-usual is characterised by predominantly reactive management, with little coordination and knowledge-sharing among actors and across scales. The sustainable alternative future is characterised by forward-looking and proactive management and planning, with extensive cooperation and knowledge sharing and a focus on long-term solutions as well as urgent actions in the short-term. 
Table 2 Indigenous and traditional views on ocean mitigation and adaptation

There was no part of the world's Ocean where traditional and Indigenous peoples did not travel, visit or know about. Even Antarctic waters were visited by the Maori centuries before European exploration of the ocean (Mustonen et al. in prep; Hulbe et al. 2010). This has also included gendered understandings of the sea, where Indigenous women have had a special access and knowledge of their own, such as on Haida Gwaii, on the Western coast of Canada (see Fischer et al. 2020).

Today when climate change is altering the seas at large we can try to discern some aspects of climate change mitigation and adaptation questions from the viewpoint of Indigenous and local or traditional knowledge and wisdom. These knowledges have baselines and understandings of the ocean of which only a fraction has ever been seen outside of these worlds.

The past 500 years of marine governance built on the dominion and greed by European settler powers has resulted in immense collapse of fish stocks, whale and marine mammal species, and other ecosystems across the planet (Díaz et al. 2019). No part of the ocean is unaffected by this legacy and on-going expansionist use of the seas (Jouffray et al. 2020). Central to this process has been the loss of traditional governance of the seas, a transfer of power from the hands of the traditional owners, users and maritime nations of the Indigenous and traditional peoples into supra-entities and also unregistered fleets, corporations and organisations that take advantage of the "Freedom of the Seas" for their unsustainable uses.

Climate change affects marine areas in a range of system altering ways, including but not limited to warmer waters, loss of coral reefs and habitats, alterations to ocean currents, species on the move, unsafe travel at sea, unpredictable weather events, loss of resources both on the coasts and at sea, and a range of intertwined events and processes as a part of this regime shift.

We can therefore ask critically what and how can Indigenous and traditional maritime peoples do in the context of mitigation and adaptation whilst having lost most of their previous global-wide access to the sea and her resources. A central answer is a return to Indigenous rights and title to the sea where possible, leaving sea and coastal areas to recover and reform in the new normal and support rewilding and restoration work where possible (Fischer et al 2020). Central to these actions are issues of power, equity and resources and lack thereof (see Ogier et al 2020).

If settler and global powers are serious in their commitment to help Indigenous and traditional communities to mitigate harm from global climate change and adapt to the new realities, they need to form a new relationship with the sea and her peoples (Frainer et al. 2020).

Some actions can be taken. The first strategic action to take across the global coastal and marine environments is to operationalise an Indigenous-science guided pause in development and industrial use of marine resources, to allow ecosystems to rebuild, reconnect and re-organise themselves in this new normal. This can come in the form of ratifying The United Nations Declaration on the Rights of Indigenous Peoples (UNDRIP), inclusion of Indigenous rights at the national EEZ level, and actively supporting Indigenous participation in international for a such as UN processes, including more inclusive participation in the production of IPCC reports.

On a tactical level, some actions may be suggested. They should be always tailored to the local context and priorities in a cogovernance manner in order to reach long-lasting solutions. For food security priorities, quotas should be given to the smallscale fleets and Indigenous harvesters (Farmery et al. 2021) as many issues result from industrial scale gear and associated bycatch issues. For anadromous fish, e.g. Atlantic Salmon, that migrate from the ocean to freshwatersto spawn, ecological restoration and conservation of Indigenous-owned catchment areas has proved a partial success in the European North (Brattland and Mustonen 2018). At the coasts, use of Indigenous knowledge and science can stimulate restoration efforts (Goldman 2019) supporting resilience (Jones et al. 2017). For heavily hit communities such as low-lying island nations and sea ice-dependent Bering Sea communities in Alaska (e.g. Shismaref, Unalakleet, and Kotzebue), use of large-scale adaptation ranging from large international aid programs through to re-location of whole communities is needed urgently.

Interventions are technical human activities specifically directed at reducing the magnitude of climate change (e.g. mitigation and carbon dioxide removal technologies) and/or dampening climate change impact pathways (e.g. adaptation and solar radiation management; Figs. 2 and 3). As an umbrella driver in the context of climate change adaptation and mitigation, the term "interventions" encompasses the innovation, research and development of new technologies and approaches (i.e. the development of tools that can be deployed to achieve adaptation, solar radiation management, mitigation and carbon dioxide removal), as well as the manner in which interventions are deployed. The business-as-usual vs. sustainable but technically achievable 2030 futures are differentiated by the degree of targeted investment, cooperation, knowledge-sharing and coordination across scales in both technological development and the deployment of interventions.

Appetite for climate action, in the context of the challenge of climate change adaptation and mitigation, is the degree to which society supports, demands 


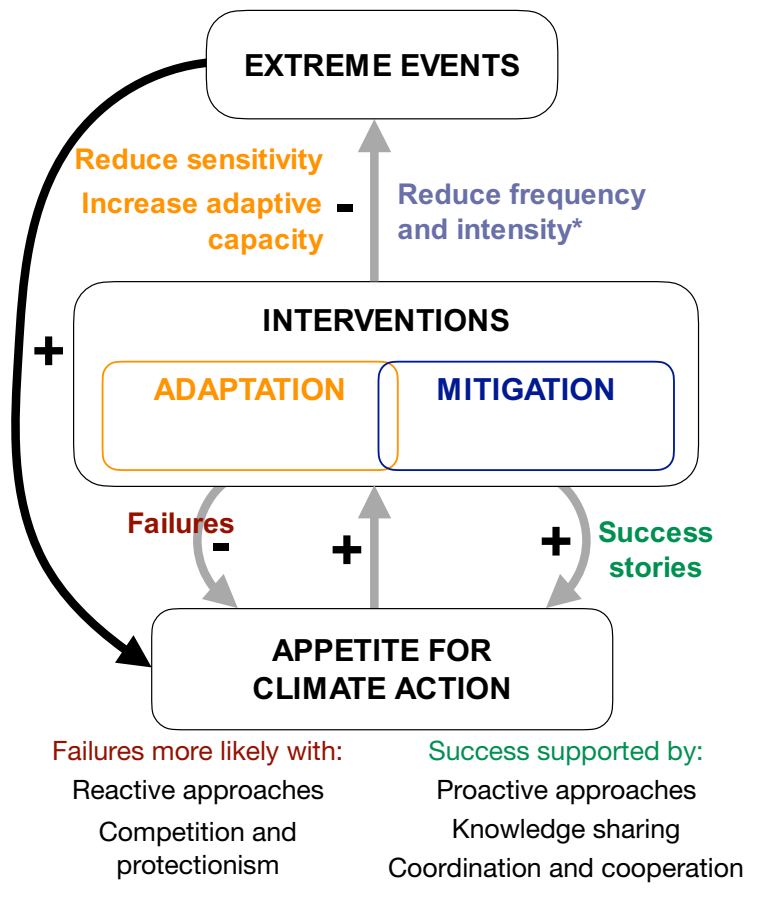

Fig. 3 Feedbacks among drivers for climate change mitigation and adaptation responses. *mitigation interventions are expected to reduce the frequency and intensity of extreme events in the long term, but even under our sustainable scenario, this effect will not be realised by the 2030 timeline

and is "willing to pay" for decisive action and interventions on climate change adaptation and mitigation. We assume that appetite for climate action will grow in response to increasing frequency and intensity of extreme events and the escalating economic and social costs exacted by them. This assumption has been supported by the response to the 2019/20 Australian bushfire crisis from the Australian public, with wide-spread calls for changes in government policy to address climate change issues (Walker 2020). The COVID-19 (SARS-CoV-2) global pandemic has also shown that governments can rapidly mobilise human and financial resources in response to life-threatening emergencies, using measures that have negative economic impacts, and still get broad support from society.

We also expect that appetite for climate action will be strengthened by success stories (i.e. tangible examples of targeted interventions and local actions with clear positive outcomes) in the short-term, and in the longer-term by education and engagement activities that build public awareness and pathways for action. In turn, we expect that as awareness and appetite increase, engagement in climate action is also expected to increase so that these activities compound and build momentum over time. This would involve the development of a shared collective goal focused on value held for, and engagement in, climate action activities which sustains such activities in the longterm. Conversely, we expect that appetite for climate action may be diminished by failed interventions and maladaptation (McDonald et al. 2019b), and that inadequate public education and engagement will lead to less appetite for action (Fig. 2; Kahan et al. 2012). Appetite for climate action is thus influenced by risk perception and effectiveness of actions. Because of the urgency to take actions to reduce climate change, the interventions required to both mitigate and adapt to climate change will be outside the range of businessas-usual actions. While some interventions may in themselves be perceived as risky, the sustainable scenario will be characterised by better accounting for the risks of inaction. An important nuance here is that our expectations for the relationship between appetite and successes vs. failures pertain to targeted interventions and local actions with effects that are clearly tangible. In this sense, not all successes will be 'success stories', that may be expected to build appetite for climate action. For example, successful large scale adaptation and mitigation strategies (e.g. national public policy, strategy and investment) may lead to questions around why the cost is necessary (see Singh et al. 2019 for a discussion of these dynamics in the context of climate impacts and future consequences across SDG targets). This underscores the importance of leveraging identifiable success stories.

A key aspect of appetite for climate action that differentiates between a business-as-usual vs. sustainable future is the willingness of individuals to bear some personal cost to support adaptation and mitigation. The business-as-usual scenario sees limited support and demand for adaptation, mitigation and climate intervention activities, provided they do not incur substantial cost or inconvenience. In contrast, in the sustainable scenario, society strongly supports and demands decisive action, and individuals are willing to personally bear costs to support wider benefit (i.e. are more altruistic).

Repair and recovery from extreme events is often costly, both financially and psychologically (Norris et al. 2002a). We assume that a proactive, cooperative 


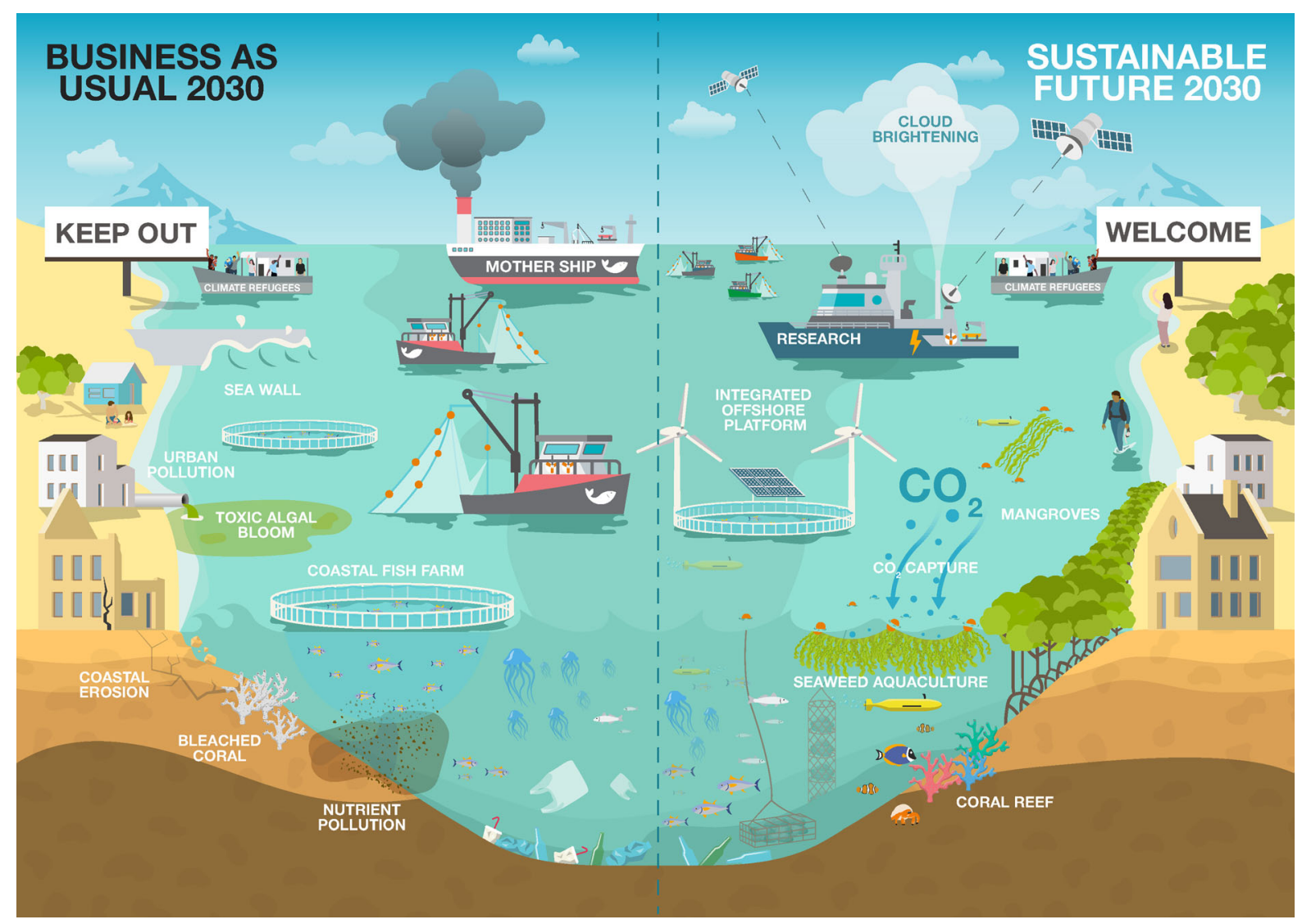

Fig. 4 Business-as-usual vs. optimistic but technically achievable futures for ocean social-ecological systems

and coordinated approach to handling extreme events will help build appetite and self-efficacy for climate action, while a reactive, fragmented approach may ultimately undermine appetite through "compassion fatigue" (Moeller 1999; Höijer 2010). Extreme events can and will disrupt adaptation and mitigation intervention efforts. For example, coastal flooding, storms and heatwaves can impact seagrass and mangrove communities (Babcock et al. 2019), so may be expected to affect the success of seagrass and mangrove restoration efforts, and storms can damage mitigation infrastructure such as offshore wind farms (Rose et al. 2012), as well as impair the psychological safety and mental health of those human communities impacted (Norris et al. 2002b).

Below we outline narratives, framed by these umbrella drivers, for today and the business-as-usual and sustainable but technically achievable scenarios for 2030 .

\section{Today's narrative: current status, trends and key challenges for mitigation and adaptation}

Worldwide, unprecedented negative impacts on marine ecosystems and dependent communities are already manifesting as a result of rising sea level, increasing frequency and intensity of coastal storms and marine heatwaves, and other factors (Oliver et al. 2017; Smale et al. 2019; Babcock et al. 2019). Storms that erode coastal habitats and flood low-lying areas are exacerbated by patterns of coastal urbanisation in many countries (Magnan et al. 2019). Climate impacts may work synergistically and exacerbate non-climate drivers. Growing human populations put enormous pressure on coastal ecosystems (Dutra et al. 2018; Abelson 2019). Highly populous coastal nations, such as Bangladesh, and small island developing states (SIDS), today already face serious and escalating threats from extreme events such as flooding (IPCC 2019) and cyclones (Dastagir 2015; Dewan 2015). 

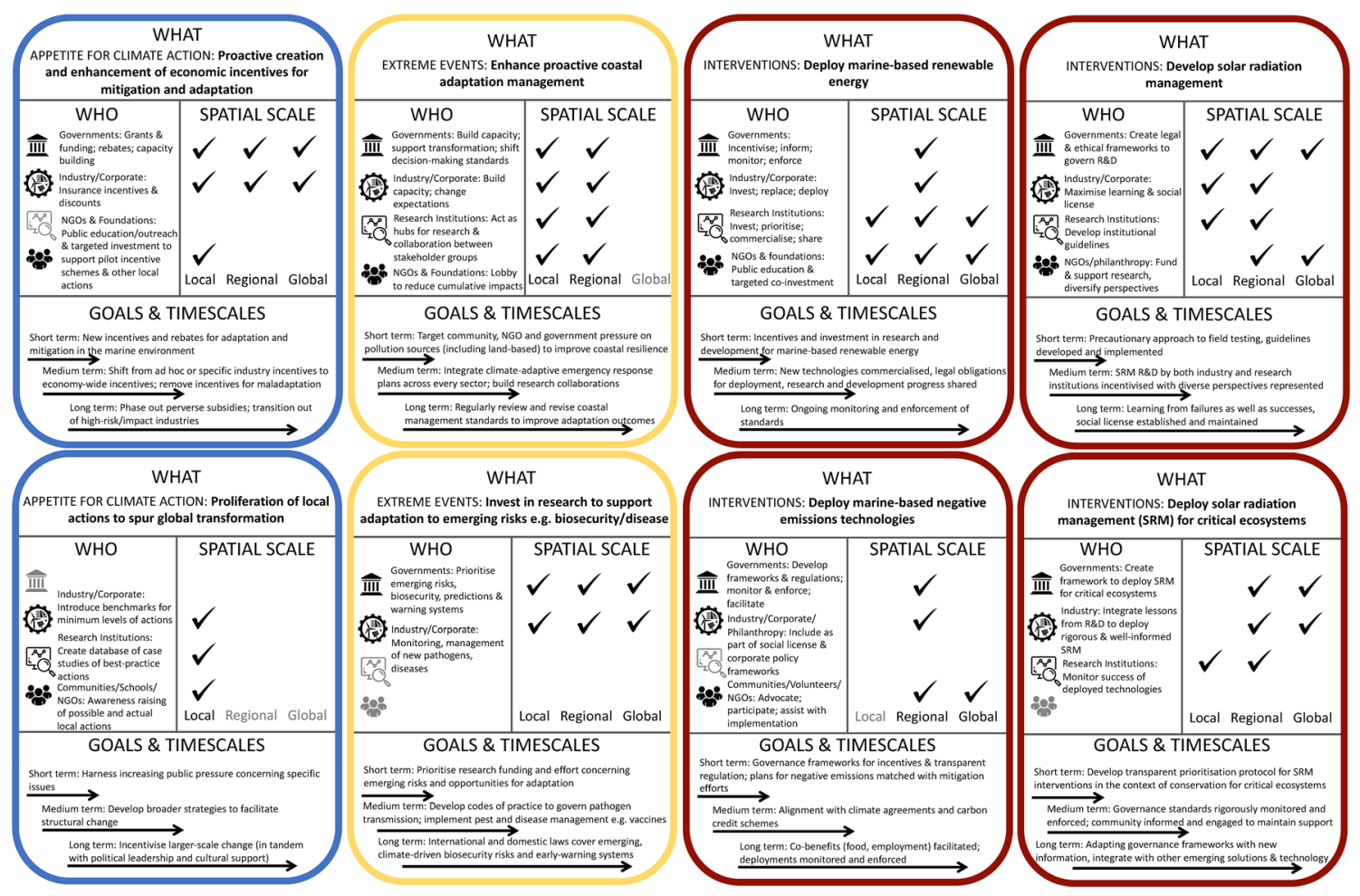

Fig. 5 Actions and timescales for navigating toward a sustainable 2030

Due to their lower income ("developing") status, these states generally do not have the resources to manage this pressure in an environmentally sustainable way without assistance. Many are increasingly vocal in asserting their need for support from wealthier ("developed") nations (Ciplet et al. 2013) although it can be difficult to quantify exactly what constitutes effective adaptation aid (Donner et al. 2016), and the assessment is rarely made by those with the greatest need and least access to power and capital.

Present-day energy use remains largely reliant on fossil fuels which are often subsidised by government (Victor 2009; Climate Transparency 2018). As a result, greenhouse gas emissions have increased on average $1.5 \%$ per year in the last 10 years (United Nations Environment Programme 2019). The opposite is necessary if the world is to achieve the Paris Agreement goal of limiting warming below $1.5-2{ }^{\circ} \mathrm{C}$ by the end of the 21 st century (IPCC 2014, 2019). Incentives for clean energy transitions at household, industrial/sectoral scales are generally insufficient to drive change (Miller et al. 2013; Burke and Stephens 2018). There is a disconnect between local-level actions to reduce $\mathrm{CO}_{2}$ emissions and the national- and global-level policy shifts and level of coordination required to achieve energy transformation (Rosenzweig et al. 2010; Rogelj et al. 2015). This has inhibited the development of shared behavioural norms that would support the development and sustainment of actions that could result in clean energy transition (Miller et al. 2013; Climate Transparency 2018). This lack of coordination can also serve as a source of confirmation bias amongst climate skeptics, who leverage the argument that government inaction must mean that climate change is not real or poses no real threat to our planet (Carey 1986; Morgan et al. 2002; Wilburn King 2019).

Mitigation interventions (those that will prevent or slow rates of greenhouse gas emissions) are currently being widely explored, including for ocean systems. In some places, they are already being trialled or deployed, albeit in an ad-hoc and uncoordinated manner (Gattuso et al. 2018). 'Low-hanging fruit' options for ocean-based mitigation include increased use of tidal, solar, wind and wave energy generation, as well as transitioning to electric power and/or 
hydrogen for shipping (Hoegh-Guldberg et al. 2019; Fig. 1).

There is growing recognition that such mitigation efforts alone cannot prevent overshoot of the Paris Agreement target of limiting warming to between 1.5 and $2{ }^{\circ} \mathrm{C}$ (IPCC 2014), and warming of $3-5^{\circ} \mathrm{C}$ is expected if the current path is not substantially changed (WMO 2019). This is prompting closer consideration of the large-scale deployment of carbon dioxide removal technologies to augment mitigation efforts, including the expansion of kelp farming and the fertilisation of ocean to promote phytoplankton growth (Williamson et al. 2012; Sondak et al. 2017; Boyd and Vivian 2019). However, these approaches, for the most part retain carbon within the carbon cycle, and true carbon sequestration -where carbon is taken out of the carbon cycle -will be necessary in the medium to long-term (GESAMP 2019). The feasibility, benefits/costs and risks to ecosystems and resources of various marine-based carbon dioxide removal interventions are still being evaluated but there have been very few field experiments (GESAMP 2019). National and international laws and associated institutions contain significant restrictions on research into marine-based carbon dioxide removal and currently fail to provide an adequate framework for regulating deployment of new carbon dioxide removal technologies (McGee et al. 2018; C2G2 2019), or other unconventional and innovative interventions (Fidelman et al. 2019). Further, should such legal/regulatory frameworks exist, they will need to be augmented with provisions to allow for experimental policy trials of novel unconventional interventions (i.e. adaptive management) and appropriate reinforcers for compliance. Typically, such reinforcers involve the use of punishment for non-compliance. However, researchers have consistently demonstrated that employment of a combination of both positive reinforcement (i.e. reward for compliance) and negative reinforcement (i.e. removal of a negative outcome in return for compliance) to guide valuesbased decision-making results in greater adherence than risk of punishment alone (Morris and Cushman 2018).

The prospect of exceeding the $2{ }^{\circ} \mathrm{C}$ threshold for dangerous climate change is also stimulating debate over the use of interventions to temporarily manage incoming solar radiation and hold temperatures in check while mitigation occurs (Boyd and Vivian
2019). Marine cloud brightening is already under consideration at local and regional scales (the first marine cloud brightening experiment was recently completed on Australia's Great Barrier Reef; https:// www.sciencealert.com/cloud-brightening-is-thenewest-experiment-to-protect-the-great-barrier-reeffrom-warming), while stratospheric aerosol injection would need to occur at the planetary-scale (GESAMP 2019). Research and development into the feasibility, efficacy and risks of these technologies is still in early stages. Currently, there is public resistance to solar radiation management interventions, but support for research into their efficacy (Scheer and Renn 2014). There is no established legal framework currently in place to manage the risks and distributive impacts of such interventions, but a growing number of researchers are exploring the potential for existing national and international law to fill this gap (McDonald et al. 2019a; Fidelman et al. 2019).

Adaptation interventions for ocean systems may target protection or enhancement of:

- key species (e.g. iconic species, Hobday et al. 2015; economically valuable species, Caputi et al. 2016; Pratchett et al. 2017; or habitat-forming species like seagrasses, mangroves and macroalgae, Duarte et al. 2013);

- entire habitats or communities (e.g. coral reefs, kelp forests; seafloor communities, Miller et al. 2018; Tittensor et al. 2019); and/or

- dependent humans, economic sectors, and social systems (e.g. relocation of communities from low lying areas prone to sea-level rise and storm surge, Magnan et al. 2019);

Adaptation interventions may also seek to anticipate and adapt to changes such as an arrival and/or increase in abundance of new species (Spijkers and Boonstra 2017; Melbourne-Thomas et al. 2021; Fig. 1). To date, adaptation interventions have predominantly been limited to single species rather than taking an ecosystem approach and have been ad hoc rather than systematically planned and coordinated across jurisdictions (Pecl et al. 2019a).

The current variety and intensity of impacts and extreme events already stretches existing marine management capacity (Glasser 2019; Dutra et al. 2019). Coordination of mitigation and adaptation intervention activities across scales of governance is lacking (Di Gregorio et al. 2019). Currently, there is 
little in the way of systemic political or cultural will to support widespread adoption of adaptive marine governance (Serrao-Neumann et al. 2016), and there is a general lack of capacity to minimise climate risk. Public support for climate action is linked to valuesbased worldviews (Moser 2010; Lockwood et al. 2012), levels of education and scientific literacy, as well as localised understanding and experience of impacts, i.e. personal salience (Egan and Mullin 2012; Scannell and Gifford 2013). Experience of coastal erosion, species range shifts and impacts of marine heatwaves (e.g. coral bleaching) all have the potential to galvanise support for both stronger ocean-based mitigation and adaptation efforts. Some highly-affected communities (e.g. small island states) are now mobilising to take local action (Worland 2019) and put pressure on wealthy nations to address climate change issues (Spratt and Dunlop 2019).

The international framework for disaster prevention and response recognises climate change as a major cause of disasters that impact human settlements (UNDRR 2015). However, the disaster risk reduction components focus on adaptation; climate mitigation is not yet widely viewed as a major factor for reducing risk of disasters (McDonald and Telesetsky 2019). Most countries have some form of disaster policy that addresses the full spectrum of "allhazards" prevention, preparedness, response and recovery actions and priorities (UNDRR 2019). Coastal adaptation strategies aim to avoid exposure, accommodate impacts, retreat from already-exposed areas or protect against impacts. Retreat and relocation are already happening in island states (e.g. Indonesia has officially announced plans to relocate its capital because of sea level rise and the village of Vunidogoloa in Fiji was relocated in 2014) with potential inundation of whole atoll Island States (e.g. Tuvalu, Kiribati and Marshall Islands; Spratt and Dunlop 2019). However, the construction of hard coastal protections is currently the preferred adaptation strategy in heavily developed coastal regions (Munich RE 2017), over accommodation or retreat. For example, an estimated $14 \%$ of the total US coastline and $60 \%$ of the total coastline of mainland China has been armoured (Ma et al. 2014; Gittman et al. 2015). Seawalls and other structures have adverse impacts on adjacent areas and coastal processes as they prevent inland migration of wetlands and mangroves and can accelerate loss of beaches and tidal wetlands. This can lead to additional impacts on biodiversity and loss of the environmental services they provide (Höijer 2010; Gittman et al. 2015). The capacity of seawalls and other hardened structures to prevent damage to the infrastructure behind them will also be reduced as climate impacts worsen (Donner and Webber 2014). Protective structures are already damaged during extreme events, (e.g. the east coast of the US following superstorm Sandy), but public sympathy for affected communities typically results in maladaptive political decisions to rebuild and fortify, rather than consider managed retreat or relocation options (Frazier et al. 2010).

To date, adaptation to extreme marine events such as heatwaves and upwelling of acidified waterhas been patchy, bottom-up, and reactive (Howard and Pecl 2019). Closing fisheries until recovery has occurred is an adaptation action of sorts, as is the restoration of depleted fisheries, such as by reseeding abalone (Caputi et al. 2019). Other reactive adaptation efforts include fishers moving to areas with cooler water to continue to access the species of interest, or to avoid mortality of animals kept in live wells on vessels (Pecl et al. 2019a). Forecasts offer the potential for proactive adaptation (Hobday et al. 2016a, b; Champion et al. 2019). Seasonal forecasts of extreme warming can allow aquaculture operators to harvest early, change stocking densities, or move location of animals that may be impacted. Stockpiling and diversifying product can also allow a business to smooth over temporary loss of production during and following extreme events. Industries that are exposed to ongoing extreme events may relocate a vulnerable production stage and implement technological solutions to support adaptation, as have shellfish farmers along the west coast of the US, who have been exposed to frequent upwelling of acidified water (Barton et al. 2015; Pershing et al. 2018).

\section{Alternative future narrative 1: business-as-usual 2030}

In the business-as-usual 2030 scenario extreme events are more common and more severe, and exposed coastal regions are facing very high, rapidly increasing costs of protection and recovery from events (Fig. 4). These impacts have started to drive displacement of coastal populations in some places - 
both planned and unplanned. As costs of repair and reconstruction rise, property insurance has become harder to obtain. In some countries, governments are filling the role as 'insurer of last resort', but demand exceeds available funds. Public funding is further diverted from 'future-proofing' and resilience-building projects in marine and coastal systems, towards post-disaster recovery programs (Tompkins and Eakin 2012; Biagini et al. 2014; Ummenhofer and Meehl 2017).

Heat stress, disease outbreaks, sedimentation, and increased storms have resulted in dramatic loss of warm-water coral reefs in increasingly widespread locations (Häussermann \& Försterra 2014, Hughes et al. 2018, GBRMPA 2019, Li et al 2020). Poleward expansion of light-dependent coral species has been limited (with few exceptions; e.g. Yamano et al. 2011) due to life history characteristics (e.g., slow growing, long lived, with limited dispersal capacity) and increase in other anthropogenic pressures (e.g. pollution, habitat destruction). However, some have begun to expand into deeper water $(>50 \mathrm{~m})$, where nonphotosynthesising coral co-exist and may provide refugia for some species (Bongaerts et al. 2017). Heat stress and storms have caused mass die-offs in mangrove forests as well as sea grasses and macroalgae in some areas (Duke et al. 2017; Babcock et al. 2019). This loss of habitat and coastal protection has in turn led to declines and collapses of fisheries, and increased exposure of coastal infrastructure and industries to inundation, erosion and storm surges (Ward et al. 2016).

More intense storm and rainfall events further erode coastal habitats (Yoshida et al. 2017; Murakami et al. 2017). Hardening of the shoreline remains the most popular adaptation response, with further declines in the amenity, recreational, cultural and biodiversity values of beaches and coastal ecosystems and the effectiveness of protective infrastructure. The capacity of older structures is exceeded in some places, prompting decisions about retreat, removal, refurbishment or replacement. Significant displacement of vulnerable communities in coastal and low-lying areas is occurring, particularly in poorer countries with less capacity to construct large-scale coastal defences (Donner and Webber 2014). Many people have limited options for relocation without support. There is greater international pressure to help climate-displaced people, but still no commitment internationally (and in some cases hostility) to doing so. There is substantially more public attention on how to manage displaced coastal populations, and escalating conflicts involving climate refugees, than on the mitigation and adaptation actions to avoid further displacement. Imposition of culturally inappropriate responses has, in some cases, led to impacted communities rejecting outside help, despite escalating risks (Norris and Anbarasu 2017), and Indigenous and traditional communities continue to be marginalised and dispossessed in their relationship with the ocean (Table 2; Fischer et al. 2020; Tauli-Corpuz et al. 2020).

Extensive deployment of wind, wave and tide energy projects is providing carbon-neutral energy for coastal communities in wealthier nations, but not in poorer countries. Where they have been deployed, these renewable energy projects have led to conflicts among marine users (Bax et al. 2021; Alexander 2019). Multiple-use platforms that combine aquaculture, renewable energy, and other activities show promise for resolving some of these conflicts, but they are yet to be deployed at a large scale. There is also concern that some technologies (e.g. offshore wind energy production) might impact wildlife populations, particularly seabirds (Köppel 2017), but a lack of coordinated observation and monitoring across jurisdictions makes assessments of impacts uncertain. The maintenance of these installations, including worker access and safety, is of growing concern due to increasingly severe ocean storms.

Kelp farms have been established in some places, aiming to contribute to carbon dioxide removal and offsetting, supported by national policies that encourage carbon dioxide removal activities (Fig. 4; Chung et al. 2011; Duarte et al. 2017; Froehlich et al. 2019). However, the effectiveness of carbon dioxide removal activities has been widely contested, and even if their effectiveness is assumed, the scale of deployment has not been adequate to substantially offset the continued rise in greenhouse gas emissions. Some nations have attempted ocean fertilisation of their waters, including through the dispersal of iron. Results have varied from place to place, but overall, the small scale of such fertilisation activities has had no impact on atmospheric carbon dioxide concentrations (GESAMP 2019). Carbon dioxide removal efforts (including restoration of blue carbon ecosystems such as mangroves and seagrasses) are consistently disrupted by extreme weather events. 
Solar radiation management research has reached the feasibility stage, following small-scale field tests of stratospheric aerosol injection and even localised deployment of marine cloud brightening over places like the Great Barrier Reef and polar ice-covered areas. A growing number of nations increasingly recognise the need to move to full-scale deployment of solar radiation management to prevent irreversible catastrophic warming, but there is still no international consensus nor international governance regime to manage transboundary risks. Governance for high-risk interventions such as stratospheric aerosol injection continues to be piecemeal and reactive at a national scale, with little integrated assessment of impacts, knowledge sharing and coordination between actors and across countries (McGee et al 2018). The continued experimentation with solar radiation management in the absence of strong governance has undermined public trust but public support is growing slowly as climate impacts worsen (McDonald et al. 2019b; Preston 2013; Scheer and Renn 2014).

Extreme events are more frequent and intense, as predicted for marine heatwaves and cyclones under RCP 4.5 and 8.5 (Gettelman et al. 2018; Oliver et al. 2019). Declines in the productivity of many fisheries forecast by the 2050/2055 time horizon are beginning to become evident, particularly at low-to-mid latitudes (Cheung et al. 2010; Barange 2014; Rousseau et al. 2019). Outbreaks of disease are more frequent (Tracy et al. 2019), leading to substantial losses for aquaculture industries (Leung and Bates 2013) and local extinctions of wild populations. Range shifts are leading to species loss from ecosystems in some areas, while new arrivals are creating management challenges elsewhere (Melbourne-Thomas et al. 2021; Spijkers and Boonstra 2017; Alexander 2019).

Despite short term spikes in appetite for climate action during and shortly after extreme climate-related events, overall, for a range of complex psychological and social reasons (Gifford 2011; McDermott and Surminski 2018), human inaction continues to lead to increasing cost and increasing inequities. Businesses and individuals try to mitigate their exposure and risk by acting on their own, in a range of ways (including choosing not to act; Bercht 2017). The lack of coordination and support across multiple levels of society and government means some adaptive actions are ineffective (Pecl et al. 2019a) and some even perpetuate the problem (e.g. increased energy use from air conditioning). Public and political discourse is centred around ascribing blame and arguing about the necessity for or pace of climate action, rather than proactive action (Bowles et al. 2015).

\section{Alternative future narrative 2: sustainable 2030}

In the optimistic, sustainable and technically achievable 2030 narrative, as in the business-as-usual scenario, the world is feeling the effects of climate change impacts that are already 'locked-in', with more frequent and severe extreme events, inundation of low-lying islands and coastal areas, and resulting displacement of coastal populations. However, this future is differentiated from the business-as-usual 2030 in that the public is more proactive in understanding the impacts of climate change on all marine systems, and there is increased appetite for implementation efforts to mitigate and adapt to climate change in ways that promote climate justice, support equity (Alexander et al. 2020; Smith et al. 2020), support Indigenous and traditional access rights (Table 2; Fischer et al. 2020) and maintain quality of life (Fig. 4). Increased public awareness and support for and willingness to bear costs of implementation has created opportunities for governments to commit to coordinated regional and global action on mitigation and adaptation and for the corporate sector to engage proactively at a sub-national level.

Governments have responded to the climate crisis and increasing pressure from industry and civil society, with commitment to and investment in ambitious mitigation, including marine-based renewables and carbon sequestration. Global greenhouse gas emissions have peaked. The large-scale deployment of a wide range of carbon dioxide removal technologies, governed by robust national laws and global policies, is starting to improve prospects of staying below the $2{ }^{\circ} \mathrm{C}$ threshold of the Paris Agreement. Following successful trials in Europe, the US and Australia, multi-use installations are being developed in many parts of the world that deliver co-benefits for food and energy production and environmental protection, including by relieving pressure on coastal regions (see https://blueeconomycrc.com.au/; Novaglio et al. 2021). The international community has also agreed to provide funding to support the roll out of a catastrophe insurance scheme for all small island states and 
developing marine nations (McGee et al. 2014) and to assist in the relocation of displaced coastal peoples, responding to loss and damage arising from climate impacts that exceed the limits of adaptation.

Climate change continues to present major risks to marine systems and nations are implementing coordinated programs of adaptation options to address unavoidable impacts. These strategies are supported by growing public, private and philanthropic funding (WOC 2020), and include restoration of degraded coastal and marine ecosystems, genetic selection of species to re-populate lost habitats, and fisheries management and aquaculture practices that adapt to species redistributions (Melbourne-Thomas et al. 2021), while also balancing food production with sustaining biodiversity and other ecosystem services (Farmery et al. 2021; Ward, Layton et al. 2020). Local and Indigenous knowledge and cultural practices are valued and prioritised in adaptation planning and interventions (Fischer et al. 2020), especially in Indigenous Marine Protected Areas ('Sea Country'; Ban and Frid 2018; Ban et al. 2018). Improved management of non-climate stressors, including coastal development, over-exploitation of fisheries, and marine pollution, is enhancing the adaptive capacity of vulnerable systems, species and human society.

While there has been significant progress in mitigation action to limit climate change, concern over the risks of overshooting $2{ }^{\circ} \mathrm{C}$ of warming has led to broad international consensus on the need for increased research and development into solar radiation management technologies. A new international legal framework and supporting national laws provide a robust protocol for research, notification, assessment, monitoring and public reporting of solar radiation management activities. Solar radiation management research and pilot interventions, in line with this protocol, have built public trust (Lacey et al. 2018) while enabling researchers to understand the efficacy, cost, and risks of available technologies. Concerns persist over the impacts of planetary scale interventions such as stratospheric aerosol injection, but rigorous programs of field testing are underway to support readiness of such large-scale interventions if observations show that predetermined thresholds are being reached faster than anticipated. There is significant support for local and regional marine cloud brightening to protect especially vulnerable ecosystems (e.g. reefs and areas of ice) while mitigation activities stabilise levels of warming, subject to strong, enforceable, participatory national laws, developed in alignment with international laws.

Interventions are coordinated across sectors and scales and aligned with relevant legal frameworks and incentives to avoid policy failure and maladaptation. As these climate interventions are rolled out, new markets and technologies emerge to collect, interpret, synthesise, analyse and distribute information about climate interventions in useful and user-friendly ways. Continued advances in ecosystem modelling and integration with observations has supported development of 'ecosystem forecasting' services (in an analogous manner to the way that climate observations and models supported the development of weather forecasting services in the last century; Gneiting 2005). Extreme events still occur, but prediction and intervention help to minimise impacts. Translocations have been successfully used to move species to emerging areas of viable habitat and 'engineer' emerging ecosystems. Ecological communities and dependent human communities have also benefited from the implementation of technological advances, such as genetic selection and breeding to support adaptation of ecosystems (e.g. coral reefs, mangroves, kelp forests) and improve fish stocks.

Coastal managers and property owners (local councils, states, individuals) are embracing a more adaptive, ecosystem-based approach to coastal management in some coastal cities and Island nations (Bax et al. 2021; blueeconomyseychelles.org/; Ajuntament de Barcelona 2020) and these are seen as blue prints for the rest of the world. Ecosystem-based coastal management and town-planning strategies are aimed at accommodating the impacts of sea level rise and extreme events, rather than avoiding or defending against them (Dafforn et al. 2018). Ecosystems remain resilient enough to deliver important ecological cobenefits. This new style of integrated adaptive coastal zone management is backed by strong policies and laws. Funds saved in shifting from hard coastal protection are directed towards supporting vulnerable communities to retreat from highly exposed areas. Political leaders remain committed to this long-term strategy, even in the aftermath of specific events when there is public pressure to focus only on affected communities. 
Appetite for climate action has built across sectors and scales. Climate action is seen as an opportunity to reimagine positive social change (Hulme 2008), rather than a reactionary impulse (Fagan 2017), supporting agency and promoting a sense of shared identity within and across communities (Scannell and Gifford 2013). Ocean and climate change literacy are core parts of school curricula (Kelly et al. 2021), as are critical thinking skills that equip individuals to reject misinformation regarding climate change. There has been considerable effort and progress in aligning and coordinating adaptation and mitigation efforts across scales (from local to international) with strong engagement of both the public and private sectors. Private-sector and public engagement has been supported by new incentive schemes such as government grants and tax breaks to support adoption of and investment in renewables, with corresponding elimination of perverse incentives such as fossil fuel subsidies for marine fisheries and transport sectors. Similarly, incentives and investment has supported knowledge-sharing and cooperation across scales and sectors, which has resulted in positive feedbacks of engagement (Jordan et al. 2018). There has also been substantial and sustained investment in adaptation planning and disaster risk reduction. Adaptation plans, financial mechanisms to deliver blue natural capital benefits (Claudet et al. 2020), policies and incentives are implemented to enable structural transformation driven by consistent risk reduction frameworks and practical advice (Gibbs 2015) and shared worldviews regarding climate change mitigation strategies (McDermott and Surminski 2018).

\section{Navigating the path toward a sustainable 2030 and beyond}

We identified eight overarching actions, associated with our umbrella drivers, that together could underpina pathway toward our sustainable 2030 scenario (Fig. 5, Table S3). For Appetite for climate action these are (i) proactive creation and enhancement of economic incentives for mitigation and adaptation, and (ii) supporting the proliferation of local actions to spur a global transformation. For Extreme events the two key actions we identified are (iii) enhancing proactive coastal adaptation management, and (iv) investing in research to support adaptation to emerging risks. For Interventions we identified four key actions: (v) deploying marine-based renewable energy and (vi) negative emissions technologies; (vii) developing solar radiation management approaches; and (viii) deploying existing and new solar radiation management approaches to help safeguard critical ecosystems.

Across all these actions, government, industry, research institutions and civil society (notably nongovernment organisations and foundations) all have key roles to play in the short, medium and long-term (Fig. 5). Coordination, cooperation and knowledgesharing across jurisdictions and scales will be essential (Gattuso et al. 2018; WOC 2020).

A key cross-cutting message is that decisionmakers and other stakeholders need ongoing support to understand the risks and benefits of novel interventions, including the risks of doing nothing (i.e. 'risk vs. risk' trade-offs). Strengthening communication of cobenefits and trade-offs among different adaptation and mitigation interventions will help facilitate this (e.g. Bindoff et al. 2019), and concerted effort and targeted research is also needed on maximising the effectiveness of science-policy linkage and knowledge exchange (Kelly et al. 2021). Fostering public support for mitigation, adaptation and geoengineering decisions requires clear and transparent reporting of these risk vs. risk and risk/benefit accountings and tradeoffs. This is not currently supported by relevant laws and policies, which typically focus on narrowly defined environmental threats from extractive activity/development, rather than addressing the risk of doing nothing and allowing climate impacts to occur unabated. Full accounting of risks and benefits does not currently underpin decision-making for marine systems anywhere in the world (although some jurisdictions are headed in the right direction with an ecosystem approach). Achieving such a full accounting for costs, benefits and risks is among the most pressing needs for achieving the ocean we need for the future we want (Ryabinin et al. 2019; Claudet et al. 2020).

Improved international governance mechanisms are required to ensure coherency in ocean-based climate action (Gattuso et al. 2018). Nevertheless, there are many opportunities for adaptation interventions that are highly likely to result in substantial tangible benefits (and avoided costs) by 2030. In contrast, mitigation interventions are not expected to 
have discernible effects by 2030 but will underpin avoidance of extreme costs in the longer-term - this is a timescale in which the 'right' or 'enough' actions can be put in place to at least be on a better trajectory. An important priority is to identify those mitigation interventions that are least likely to have negative consequences for the ocean, while also adding value to delivering SDGs (e.g. restoration efforts). Renewable energy is a 'no-regret' measure, ready for immediate widespread deployment (Gattuso et al. 2018). There is a legitimate concern that a greater focus on adaptation and solar radiation management may provide a "moral hazard" dilemma, in that these actions might decrease effort on emissions reduction (Preston 2013; McLaren 2016). However, the level of climate change that has already occurred $\left(1.1^{\circ} \mathrm{C}\right)$ and that is already locked in for the future (at least $0.4{ }^{\circ} \mathrm{C}$; IPCC 2019) means that mitigation action alone will not be enough to protect human communities from significant costs. It is critical to communicate clearly to policymakers and the public that all of mitigation, adaptation and solar radiation management are important and action in one area should not be to the detriment of resources and effort in another.

A more comprehensive set of measures to enable greater equity in the delivery of suitable outcomes, including rationalisation of the range of incentives that surround mitigation and adaptation interventions, will also be essential to achieving a 2030 aligned with the SDGs and the sustainable scenario that we describe here. In the short term, this could take the form of targeted rebates and incentive schemes (e.g. tax breaks), expanding over time to be economy-wide. In addition to introducing new incentives, this will also involve removing incentives for maladaptation and phasing out perverse subsidies. Governments will likely play a central role through grants, funding, rebates and capacity building. Industry engagement will also be important, notably from the insurance industry where there is likely to be the opportunity for incentives and discounts to encourage adaptation.

Financial and other incentives for mitigation, adaptation and solar radiation management research, development and uptake will need to be coordinated, or at least not conflicting, across locations and scales. Uptake of incentives by business and NGOs will be important to ensure that they contribute to action, and there is strong potential for targeted investment and leadership from industry and civil-society foundations to help catalyze this. In order to be effective, incentives will need to have appeal beyond climate change to deliver broad ocean-based natural capital benefits-e.g. an adequate system to finance blue economy development, financial savings, public perception of businesses, and sustainability of organisational practices (Claudet et al. 2020). Drawing on learning theory principles, incentives need to be desirable (i.e. be relevant and of use to the organisation/individual) and allow for regular rewards for early success before being offered on an intermittent schedule to develop lasting behavioural change (Cohen et al. 1994). Importantly, repeated engagement with the desired behaviour can perpetuate climate action beyond the need for incentives through the development of personal values aligned with climate action which motivate behaviour to be consistent with such values (Bardi and Schwartz 2003), supporting long-term behavioural change (Katz 2011). Public education will be key to achieving acceptance and support of new incentive approaches, and NGOs and foundations are likely to be well positioned to deploy public education and outreach activities to support this.

Change at the scale required to achieve the sustainable version of the futures described in this paper will require cooperation, coordination, and knowledge-sharing across scales and jurisdictions. An important part of this will be developing the social processes to: recognise, acknowledge and respect Indigenous ways of knowing the ocean; allow communities to learn from each other, and understand and accept risks and change; and to support the trial and implementation of novel solutions in an adaptive manner (Goddard 2016). National and subnational governments will need to experiment with ecosystembased coastal adaptation strategies, such as the Netherlands Room for the River Programme (https:// www.ruimtevoorderivier.nl/english/https://www.

ruimtevoorderivier.nl/english/), and develop processes for sharing experiences and findings. This also requires development of a shared global identity and associated altruistic behaviours when it comes to climate change. Local actions also have an important role to play in this context because of their potential to increase personal salience and agency, thereby increasing motivation for, and likelihood of, behavioural change (Scannell and Gifford 2013). 


\section{Conclusions}

In this paper, we aimed to use our collective experience to understand how society may respond positively to the immense challenges currently being faced by the oceans as a result of climate change and other pressures. We have used two scenarios, rather than an exhaustive set, in a repeatable "expert-driven" process to identify important drivers of change and pathways for action. The two scenarios are intended to frame and stimulate further research to better clarify how to achieve sustainable oceans. We found this process to be rewarding individually and encourage others to undertake similar assessments in order that realistic, long-lasting solutions may rapidly consolidate across the scientific community, along with practical actions that can be easily applied in communities and society generally. We hope that this paper provides a useful contribution toward addressing the immense challenges currently facing society in responding to the effects of climate change on ocean systems. Without such attempts, alternative framings of the future cannot be used to motivate actions. The actions required for the sustainable pathway and future are technically achievable, but whether many of these actions are 'realistic' may ultimately be a matter of opinion and will be contingent on societal and political appetite for implementation. We hope that laying out the alternative scenarios and actions that could underpin the sustainable pathway will provide inspiration and motivation to help make it both technically achievable and clearly realistic.

Our treatment of the issue of climate change adaptation and mitigation for the ocean, and specifically what might be done in this space in the 2021-2030 timeframe to move towards a future more aligned with the SDGs, is not intended to be exhaustive. Moreover, the effects of the 2020 COVID-19 pandemic mean that some of the drivers and related actions we describe are currently in a state of flux. While we do not yet have the evidence to identify how these might look once the pandemic has passed, the current disruptions that COVID-19 is causing to the global ocean, environment and society may indeed present a platform for change and an opportunity to 'reset' trajectories in the coming decade. The sustainable future presented here is one option for such a shift.
Supporting resilient marine social-ecological systems and achieving sustainable development into the future both depend critically on urgent and ambitious emissions reductions coupled with coordinated, sustained and increasingly ambitious mitigation and adaptation actions. Furthermore, strong and intensifying cooperation and coordination among governing authorities across spatial scales and planning horizons will be a fundamental enabler for climate action. These ingredients, along with strong investment in education and climate literacy, monitoring and forecasting, data sharing, and addressing social vulnerability and equity will underpin the future of the resilient marine systems that society needs and wants.

Acknowledgements This paper is part of the 'Future Seas' initiative (www.FutureSeas2030.org), hosted by the Centre for Marine Socioecology at the University of Tasmania. This initiative delivers a series of journal articles addressing key challenges for the UN International Decade of Ocean Science for Sustainable Development 2021-2030. The general concepts and methods applied in many of these papers were developed in large collaborative workshops involving more participants than listed as co-authors here, and we are grateful for their collective input. Thank you to Camilla Novaglio and Karen Alexander for providing an internal project review of an earlier draft and to Robert Stephenson and two anonymous reviewers for constructive feedback that strengthened this manuscript. We acknowledge and pay respect to the traditional owners and custodians of sea country all around the world, and recognise their collective wisdom and knowledge of our oceans and coasts. Funding for Future Seas was provided by the Centre for Marine Socioecology, IMAS, MENZIES and the College of Arts, Law and Education, and the College of Science and Engineering at UTAS, and Snowchange from Finland. We acknowledge support from a Research Enhancement Program grant from the DVCR Office at UTAS. A.M. acknowledges support from the ARC Centre of Excellence for Climate Extremes (CE170100023). GP was supported by an ARC Future Fellowship.

Funding Funding for Future Seas was provided by the Centre for Marine Socioecology, IMAS, MENZIES and the College of Arts, Law and Education, and the College of Science and Engineering at UTAS, and Snowchange from Finland. We acknowledge support from a Research Enhancement Program grant from the DVCR Office at UTAS.

Availability of data and material Not applicable.

Code availability Not applicable.

\section{Declarations}

Conflict of interest The authors declared that they have no conflict of interest. 
Ethical approval Not applicable.

Consent to participate Not applicable.

Consent for publication Not applicable.

\section{References}

Abelson A (2019) Are we sacrificing the future of coral reefs on the altar of the "climate change" narrative? ICES J Mar Sci. https://doi.org/10.1093/icesjms/fsz226

Alexander KA (2019) Conflicts over marine and coastal common resources, 1st edn. Routledge

Alexander KA, Fleming A, Dambacher JM et al (2020) Equity of our future oceans: reflections on outcomes and practice. Authorea. https://doi.org/10.22541/au.160761569. 97952359/v1

Arafeh-Dalmau N, Montaño-Moctezuma G, Martínez JA et al (2019) Extreme marine heatwaves alter kelp forest community near its equatorward distribution limit. Front Mar Sci 6:499. https://doi.org/10.3389/fmars.2019.00499

Babcock RC, Bustamante RH, Fulton EA et al (2019) Severe continental-scale impacts of climate change are happening now: extreme climate events impact marine habitat forming communities along 45\% of Australia's coast. Front Mar Sci 6:411. https://doi.org/10.3389/fmars.2019.00411

Ban NC, Frid A (2018) Indigenous peoples' rights and marine protected areas. Mar Policy 87:180-185. https://doi.org/10. 1016/j.marpol.2017.10.020

Ban NC, Frid A, Reid M et al (2018) Incorporate indigenous perspectives for impactful research and effective management. Nat Ecol Evol 2:1680-1683. https://doi.org/10. 1038/s41559-018-0706-0

Barange M, Merino G, Blanchard JL, Scholtens J, Harle J, Allison EH, Allen JI, Holt J, Jennings S (2014) Impacts of climate change on marine ecosystem production in societies dependent on fisheries. Nature Clim Change 4:211-216. https://doi.org/10.1038/nclimate2119

Bardi A, Schwartz SH (2003) Values and behavior: strength and structure of relations. Pers Soc Psychol Bull 29:1207-1220. https://doi.org/10.1177/ 0146167203254602

Barton A, Waldbusser GG, Feely RA et al (2015) Impacts of coastal acidification on the pacific northwest shellfish industry and adaptation strategies implemented in response. Oceanography 25:146-159. https://doi.org/10. 5670/oceanog.2015.38

Bax N, Novaglio C, Maxwell KE et al (2021) Ocean resource use: building the coastal blue economy. Rev Fish Biol Fish. https://doi.org/10.1007/s11160-021-09636-0

Bellprat O, Guemas V, Doblas-Reyes F, Donat MG (2019) Towards reliable extreme weather and climate event attribution. Nat Commun 10:1732. https://doi.org/10.1038/ s41467-019-09729-2

Bercht AL (2017) No climate change salience in Lofoten fisheries? A comment on understanding the need for adaptation in natural resource-dependent communities. Clim Change 144:565-572. https://doi.org/10.1007/s10584-017-2061-6

Bergstrom DM, Wienecke BC, van denHoff J et al (2021) Combating ecosystem collapse from the tropics to the Antarctic. Glob Change Biol 27:1692-1703. https://doi. org/10.1111/gcb.15539

Biagini B, Bierbaum R, Stults M et al (2014) A typology of adaptation actions: a global look at climate adaptation actions financed through the global environment facility. Glob Environ Change 25:97-108. https://doi.org/10.1016/ j.gloenvcha.2014.01.003

Bindoff NL, Cheung WWL, Kairo JG, et al (2019) Changing ocean, marine ecosystems, and dependent communities. In: Pörtner H-O, Roberts DC, Masson-Delmotte V et al. (eds) IPCC Special report on the ocean and cryosphere in a changing climate. $\mathrm{p} 142$

Bongaerts P, Riginos C, Brunner R et al (2017) Deep reefs are not universal refuges: reseeding potential varies among coral species. Sci Adv 3:e1602373. https://doi.org/10. 1126/sciadv.1602373

Bowles DC, Butler CD, Morisetti N (2015) Climate change, conflict and health. J R Soc Med 108:390-395. https://doi. org/10.1177/0141076815603234

Boyd P, Vivian C (2019) Should we fertilize oceans or seed clouds? No one knows. Nature 570:155-157. https://doi. org/10.1038/d41586-019-01790-7

Brattland C, Mustonen T (2018) How traditional knowledge comes to matter in Atlantic Salmon Governance in Norway and Finland. Arctic 71:375-392. https://doi.org/10.14430/ $\operatorname{arctic} 4751$

Brierley C, Koch A, Ilyas M, et al (2019) Half the world's population already experiences years $1.5^{\circ} \mathrm{C}$ warmer than preindustrial. Earth ArXiv. https://doi.org/10.31223/osf.io/ $\operatorname{sbc} 3 \mathrm{f}$

Burke MJ, Stephens JC (2018) Political power and renewable energy futures: a critical review. Energy Res Soc Sci 35:78-93. https://doi.org/10.1016/j.erss.2017.10.018

C2G2 (2019) Geoengineering: the need for governance. Carnegie Climate Geoengineering Governance Initiative (C2G2), February 2019, New York, USA.

Cai W, Wang G, Santoso A et al (2015) Increased frequency of extreme La Niña events under greenhouse warming. Nat Clim Change 5:132-137. https://doi.org/10.1038/ nclimate 2492

Caputi N, Kangas M, Denham A et al (2016) Management adaptation of invertebrate fisheries to an extreme marine heat wave event at a global warming hot spot. Ecol Evol 6:3583-3593. https://doi.org/10.1002/ece3.2137

Caputi N, Kangas M, Chandrapavan A et al (2019) Factors affecting the recovery of invertebrate stocks from the 2011 Western Australian extreme marine heatwave. Front Mar Sci 6:484. https://doi.org/10.3389/fmars.2019.00484

Carey S (1986) Cognitive science and science education. Am Psychol 41:1123-1130

Carey JM, Burgman MA (2008) Linguistic uncertainty in qualitative risk analysis and how to minimize it. Ann N Y Acad Sci 1128:13-17. https://doi.org/10.1196/annals. 1399.003

Champion C, Hobday AJ, Zhang X et al (2019) Changing windows of opportunity: past and future climate-driven shifts in temporal persistence of kingfish (Seriola lalandi) 
oceanographic habitat within south-eastern Australian bioregions. Mar Freshw Res 70:33. https://doi.org/10. 1071/MF17387

Cheng L, Abraham J, Hausfather Z, Trenberth KE (2019) How fast are the oceans warming? Science 363(6423):128-129

Cheng L, Abraham J, Zhu J et al (2020) Record-setting ocean warmth continued in 2019. Adv Atmos Sci 37:137-142. https://doi.org/10.1007/s00376-020-9283-7

Cheung WWL, Lam VWY, Sarmiento JL et al (2010) Largescale redistribution of maximum fisheries catch potential in the global ocean under climate change: climate change impacts on catch potential. Glob Change Biol 16:24-35. https://doi.org/10.1111/j.1365-2486.2009.01995.x

Chung IK et al (2011) Using marine macroalgae for carbon sequestration: a critical appraisal. J Appl Phycol 23:877-886. https://doi.org/10.1007/s10811-010-9604-9

Ciplet D, Roberts JT, Khan M (2013) The politics of international climate adaptation funding: justice and divisions in the greenhouse. Glob Environ Polit 13:49-68. https://doi. org/10.1162/GLEP_a_00153

Claudet J, Bopp L, Cheung WWL et al (2020) A roadmap for using the UN decade of ocean science for sustainable development in support of science, policy, and action. One Earth 2:34-42. https://doi.org/10.1016/j.oneear.2019.10. 012

Climate Transparency (2018) Brown to green report 2018: The G20 transition to a low-carbon economy. Berlin, Humboldt-Viadrina Governance Platform

Coffey R, Paul MJ, Stamp J et al (2019) A review of water quality responses to air temperature and precipitation changes 2: nutrients, algal blooms, sediment, pathogens. JAWRA J Am Water Resour Assoc 55:844-868. https:// doi.org/10.1111/1752-1688.12711

Cohen SL, Pedersen J, Kinney GG, Myers J (1994) Effects of reinforcement history on responding under progressiveratio schedules of reinforcement. J Exp Anal Behav 61:375-387. https://doi.org/10.1901/jeab.1994.61-375

Creighton C, Hobday AJ, Lockwood M, Pecl GT (2016) Adapting management of marine environments to a changing climate: a checklist to guide reform and assess progress. Ecosystems 19:187-219. https://doi.org/10.1007/ s10021-015-9925-2

Cvitanovic C, Hobday AJ, McDonald J et al (2018) Governing fisheries through the critical decade: the role and utility of polycentric systems. Rev Fish Biol Fish 28:1-18. https:// doi.org/10.1007/s11160-017-9495-9

Dafforn KA, Bugnot A, Heery E, Mayer-Pinto M (2018) Future 'ocean cities' need green engineering above and below the waterline. The Conversation. https://theconversation.com/ future-ocean-cities-need-green-engineering-above-andbelow-the-waterline-93843

Dastagir MR (2015) Modeling recent climate change induced extreme events in Bangladesh: a review. Weather Clim Extrem 7:49-60. https://doi.org/10.1016/j.wace.2014.10. 003

de Barcelona A (2020) This is not a drill: climate emergency declaration. Barcelona City Council, Spain

Dewan TH (2015) Societal impacts and vulnerability to floods in Bangladesh and Nepal. Weather Clim Extrem 7:36-42. https://doi.org/10.1016/j.wace.2014.11.001
Di Gregorio M, Fatorelli L, Paavola J et al (2019) Multi-level governance and power in climate change policy networks. Glob Environ Change 54:64-77. https://doi.org/10.1016/j. gloenvcha.2018.10.003

Díaz S, Settele J, Brondízio ES et al (2019) Pervasive humandriven decline of life on Earth points to the need for transformative change. Science. https://doi.org/10.1126/ science. aax 3100

Donner SD, Webber S (2014) Obstacles to climate change adaptation decisions: a case study of sea-level rise and coastal protection measures in Kiribati. Sustain Sci 9:331-345. https://doi.org/10.1007/s11625-014-0242-z

Donner SD, Kandlikar M, Webber S (2016) Measuring and tracking the flow of climate change adaptation aid to the developing world. Environ Res Lett 11:054006. https://doi. org/10.1088/1748-9326/11/5/054006

Duarte CM, Losada IJ, Hendriks IE et al (2013) The role of coastal plant communities for climate change mitigation and adaptation. Nat Clim Change 3:961-968. https://doi. org/10.1038/nclimate 1970

Duarte CM et al (2017) Can seaweed farming play a role in climate change mitigation and adaptation? Front Mar Sci. https://doi.org/10.3389/fmars.2017.00100

Duke NC, Kovacs JM, Griffiths AD et al (2017) Large-scale dieback of mangroves in Australia. Mar Freshw Res 68:1816. https://doi.org/10.1071/MF16322

Dutra LXC, Sporne I, Haward M et al (2019) Governance mapping: a framework for assessing the adaptive capacity of marine resource governance to environmental change. Mar Policy 106:103392. https://doi.org/10.1016/j.marpol. 2018.12.011

Dutra LXC, Haywood MDE, Singh SS et al (2018) Impacts of climate change on corals relevant to the Pacific Islands. In: Townhill B, Buckley P (eds) Pacific marine climate change report card. Commonwealth Marine Economies Programme, London

Egan PJ, Mullin M (2012) Turning personal experience into political attitudes: the effect of local weather on Americans' perceptions about global warming. J Polit 74:796-809. https://doi.org/10.1017/S0022381612000448

Fagan M (2017) Who's afraid of the ecological apocalypse? Climate change and the production of the ethical subject. Br J Polit Int Relat 19:225-244. https://doi.org/10.1177/ 1369148116687534

Farmery AK, Alexander K, Anderson K, Blanchard JL, Carter CG, Evans K, Fischer M, Fleming A, Frusher S, Fulton EA, Haas B, MacLeod CK, Murray L, Nash KL, Pecl GT, Rousseau Y, Trebilco R, van Putten IE et al (2021) Food for all: designing sustainable and secure future seafood systems. Rev Fish Biol Fish. https://doi.org/10.1007/s11160021-09663-X

Fidelman P, McGrath C, Newlands M et al (2019) Regulatory implications of coral reef restoration and adaptation under a changing climate. Environ Sci Policy 100:221-229. https://doi.org/10.1016/j.envsci.2019.04.016

Fischer M, Maxwell K, Frederiksen N et al (2020) Empowering her guardians to nurture our oceans future. Authorea. https://doi.org/10.22541/au.160391058.89181791/v1

Frainer A, Mustonen T, Hugu S, Andreeva T, Arttijeff E-M, Arttijeff I-S, Brizoela F et al (2020) Opinion: cultural and linguistic diversities are underappreciated pillars of 
biodiversity. In: Proceedings of the national academy of sciences, vol 117, no. 43, pp 26539-26543. https://doi.org/ 10.1073/pnas.2019469117

Frazier TG, Wood N, Yarnal B (2010) Stakeholder perspectives on land-use strategies for adapting to climate-change-enhanced coastal hazards: Sarasota, Florida. Appl Geogr 30:506-517. https://doi.org/10.1016/j.apgeog.2010.05.007

Freeth R, Caniglia G (2020) Learning to collaborate while collaborating: advancing interdisciplinary sustainability research. Sustain Sci 15:247-261. https://doi.org/10.1007/ s11625-019-00701-z

Froehlich HE et al (2019) Blue growth potential to mitigate climate change through seaweed offsetting. Curr Biol. https://doi.org/10.1016/j.cub.2019.07.041

Gattuso J-P, Magnan AK, Bopp L et al (2018) Ocean solutions to address climate change and its effects on marine ecosystems. Front Mar Sci 5:337. https://doi.org/10.3389/ fmars.2018.00337

GBRMPA(2019) Great Barrier Reef Outlook Report 2019, Great Barrier Reef Marine Park Authority, Townsville, Australia.

GESAMP (2019) High level review of a wide range of proposed marine geoengineering techniques. IMO/FAO/UNESCOIOC/UNIDO/WMO/IAEA/UN/UN Environment/ UNDP/ ISA Joint Group of Experts on the Scientific Aspects of Marine Environmental Protection. Rep. Stud. GESAMP No. 98, 144 p.

Gettelman A, Bresch DN, Chen CC et al (2018) Projections of future tropical cyclone damage with a high-resolution global climate model. Clim Change 146:575-585. https:// doi.org/10.1007/s10584-017-1902-7

Gibbs MT (2015) Pitfalls in developing coastal climate adaptation responses. Clim Risk Manag 8:1-8. https://doi.org/ 10.1016/j.crm.2015.05.001

Gifford R (2011) The dragons of inaction: psychological barriers that limit climate change mitigation and adaptation. Am Psychol 66:290-302. https://doi.org/10.1037/ a0023566

Gittman RK, Fodrie FJ, Popowich AM et al (2015) Engineering away our natural defenses: an analysis of shoreline hardening in the US. Front Ecol Environ 13:301-307. https:// doi.org/10.1890/150065

Glasser R (2019) Preparing for the era of disasters. Special Report. The Australian Strategic Policy Institute

Gneiting T (2005) Atmospheric science: weather forecasting with ensemble methods. Science 310:248-249. https://doi. org/10.1126/science. 1115255

Goddard L (2016) From science to service. Science 353:1366-1367. https://doi.org/10.1126/science.aag3087

Goldman JG (2019) Haida Gwaii's kelp forests disappeared. Here's how they're being brought back to life. The Narwhal. https://thenarwhal.ca/haida-gwaiis-kelp-forestsdisappeared-heres-how-theyre-being-brought-back-tolife/

Harrington LJ, Lewis S, Perkins-Kirkpatrick SE et al (2019) Embracing the complexity of extreme weather events when quantifying their likelihood of recurrence in a warming world. Environ Res Lett 14:024018. https://doi.org/10. 1088/1748-9326/aaf2dc
Häussermann V, Försterra G (2014) Vast reef-like accumulation of the hydrocoral Errina antarctica (Cnidaria, Hydrozoa) wiped out in Central Patagonia. Coral Reefs 33(1):29-29

Hinkel J, van Vuuren DP, Nicholls RJ, Klein RJT (2013) The effects of adaptation and mitigation on coastal flood impacts during the 21st century. An application of the DIVA and IMAGE models. Clim Change 117:783-794. https://doi.org/10.1007/s10584-012-0564-8

Hobday AJ, Cvitanovic C (2017) Preparing Australian fisheries for the critical decade: insights from the past 25 years. Mar Freshw Res 68:1779. https://doi.org/10.1071/MF16393

Hobday AJ, Chambers LE, Arnould JPY (2015) Prioritizing climate change adaptation options for iconic marine species. Biodivers Conserv 24:3449-3468. https://doi.org/10. 1007/s10531-015-1007-4

Hobday AJ, Cochrane K, Downey-Breedt N et al (2016a) Planning adaptation to climate change in fast-warming marine regions with seafood-dependent coastal communities. Rev Fish Biol Fish 26:249-264. https://doi.org/10. 1007/s11160-016-9419-0

Hobday AJ, Spillman CM, Paige Eveson J, Hartog JR (2016b) Seasonal forecasting for decision support in marine fisheries and aquaculture. Fish Oceanogr 25:45-56. https://doi. org/10.1111/fog. 12083

Hoegh-Guldberg O, Caldeira K, Chopin T, et al (2019) The Ocean as a Solution for Climate Change: Five Opportunities for Action. World Resources Institute, Washington, DC. Available online at http://www.oceanpanel.org/ climate

Höijer B (2010) Emotional anchoring and objectification in the media reporting on climate change. Public Underst Sci 19:717-731. https://doi.org/10.1177/0963662509348863

Howard PL, Pecl GT (2019) Introduction: autochthonous human adaptation to biodiversity change in the anthropocene. Ambio 48:1389-1400. https://doi.org/10.1007/ s13280-019-01283-x

Howard J, Sutton-Grier A, Herr D et al (2017) Clarifying the role of coastal and marine systems in climate mitigation. Front Ecol Environ 15:42-50. https://doi.org/10.1002/fee. 1451

Hughes TP, Kerry JT, Álvarez-Noriega M et al (2017) Global warming and recurrent mass bleaching of corals. Nature 543:373-377. https://doi.org/10.1038/nature21707

Hughes TP, Anderson KD, Connolly SR et al (2018) Spatial and temporal patterns of mass bleaching of corals in the anthropocene. Science 359:80-83. https://doi.org/10.1126/ science.aan 8048

Hulbe CL, Wang W, Ommanney S (2010) Women in glaciology, a historical perspective. J Glaciol 56:944-964. https:// doi.org/10.3189/002214311796406202

Hulme M (2008) The conquering of climate: discourses of fear and their dissolution. Geogr J 174:5-16. https://doi.org/10. 1111/j.1475-4959.2008.00266.x

IOC, UNESCO (2017) Information document: international (UN) decade of ocean science for sustainable development "towards the ocean we need for the future we want"

IOC, UNESCO (2019) The Science we Need for the Ocean We Want: The United Nations Decade of Ocean Science for Sustainable Development (2021-2030). Paris. 24 pp. (English) IOC Brochure 2018-7 (IOC/BRO/2018/7 Rev). 
IPCC (2014) Climate change 2014: mitigation of climate change: working group III contribution to the fifth assessment report of the intergovernmental panel on climate change. Cambridge University Press, New York

IPCC (2019) Summary for Policymakers. In: Masson-Delmotte V, Zhai P, Pörtner HO, et al. (eds) Global Warming of $1.5^{\circ} \mathrm{C}$. An IPCC Special Report on the impacts of global warming of $1.5^{\circ} \mathrm{C}$ above pre-industrial levels and related global greenhouse gas emission pathways, in the context of strengthening the global response to the threat of climate change, sustainable development, and efforts to eradicate poverty

Jones R, Rigg C, Pinkerton E (2017) Strategies for assertion of conservation and local management rights: a Haida Gwaii herring story. Mar Policy 80:154-167. https://doi.org/10. 1016/j.marpol.2016.09.031

Jordan A, Huitema D, van Asselt H, Forster J (eds) (2018) Governing climate change: polycentricity in action?, 1st edn. Cambridge University Press, Cambridge

Jouffray J-B, Blasiak R, Norström AV et al (2020) The blue acceleration: the trajectory of human expansion into the ocean. One Earth 2:43-54. https://doi.org/10.1016/j. oneear.2019.12.016

Jupiter SD et al (2017) A social-ecological systems approach to assessing conservation and fisheries outcomes in Fijian locally managed marine areas. Soc Nat Resour 30:1096-1111

Kahan DM, Peters E, Wittlin M et al (2012) The polarizing impact of science literacy and numeracy on perceived climate change risks. Nat Clim Chang 2(10):732-735

Katz PS (2011) Neural mechanisms underlying the evolvability of behaviour. Philos Trans R Soc B Biol Sci 366:2086-2099. https://doi.org/10.1098/rstb.2010.0336

Kelly R, Evans K, Alexander KA et al (2021) Connecting to the oceans: supporting ocean literacy and public engagement. Rev Fish Biol Fishdoi. https://doi.org/10.1007/s11160020-09625-9

Köppel J (ed) (2017) Wind energy and wildlife interactions. Springer International Publishing, Cham

Kumagai NH, García Molinos J, Yamano H et al (2018) Ocean currents and herbivory drive macroalgae-to-coral community shift under climate warming. Proc Natl Acad Sci 115:8990-8995. https://doi.org/10.1073/pnas.1716826115

Lacey J, Howden M, Cvitanovic C, Colvin RM (2018) Understanding and managing trust at the climate science-policy interface. Nat Clim Change 8:22-28. https://doi.org/10. 1038/s41558-017-0010-z

Leung TLF, Bates AE (2013) More rapid and severe disease outbreaks for aquaculture at the tropics: implications for food security. J Appl Ecol 50:215-222. https://doi.org/10. 1111/1365-2644.12017

Li J et al (2020) A global coral reef probability map generated using convolutional neural networks. Coral Reefs 39(6): 1805-1815

Lockwood M, Davidson J, Hockings M et al (2012) Marine biodiversity conservation governance and management: Regime requirements for global environmental change. Ocean Coast Manag 69:160-172. https://doi.org/10.1016/j. ocecoaman.2012.07.015
Ma Z, Melville DS, Liu J et al (2014) Rethinking China's new great wall. Science 346:912-914. https://doi.org/10.1126/ science. 1257258

Magnan AK, Garschagen M, Gattuso J-P et al (2019) Integrative cross-chapter box on low-lying islands and coasts. In: Pörtner H-O, Roberts DC, Masson-Delmotte V, et al. (eds) IPCC Special report on the ocean and cryosphere in a changing climate. $\mathrm{p} 18$

Marshall NA, Tobin RC, Marshall PA et al (2013) Social vulnerability of marine resource users to extreme weather events. Ecosystems 16:797-809. https://doi.org/10.1007/ s10021-013-9651-6

McDermott TKJ, Surminski S (2018) How normative interpretations of climate risk assessment affect local decisionmaking: an exploratory study at the city scale in Cork, Ireland. Philos Trans R Soc Math Phys Eng Sci 376:20170300. https://doi.org/10.1098/rsta.2017.0300

McDonald J, Telesetsky A (2019) Disaster by degrees: the implications of the IPCC $1.5^{\circ} \mathrm{C}$ report for disaster law. Yearb Int Disaster Law 1:179-209. https://doi.org/10. 1163/26662531-01001010

McDonald J, McGee J, Brent K, Burns W (2019a) Governing geoengineering research for the great barrier reef. Clim Policy 19:801-811. https://doi.org/10.1080/14693062. 2019.1592742

McDonald KS, Hobday AJ, Thompson PA et al (2019b) Proactive, reactive, and inactive pathways for scientists in a changing world. Earths Future 7:60-73. https://doi.org/10. 1029/2018EF000990

McGee J, Phelan L, Wenta J (2014) Writing the fine print: developing regional insurance for climate change adaptation in the pacific. Melb J Int Law 15:444-472

McGee J, Brent K, Burns W (2018) Geoengineering the oceans: an emerging frontier in international climate change governance. Aust J Marit Ocean Aff 10:67-80. https://doi.org/ 10.1080/18366503.2017.1400899

McLaren D (2016) Mitigation deterrence and the "moral hazard" of solar radiation management. Earths Future 4:596-602. https://doi.org/10.1002/2016EF000445

Melbourne-Thomas J, Audzijonyte A, Brasier M et al (2021) Poleward bound: adapting to climate driven species redistribution. Rev Fish Biol Fish. https://doi.org/10.1007/ s11160-021-09641-3

Melbourne-Thomas J, McInnes K, Bindoff NL, Abram N (2019) A landmark report confirms Australia is girt by hotter, higher seas. But there's still time to act. The Conversation. https://theconversation.com/a-landmark-report-confirmsaustralia-is-girt-by-hotter-higher-seas-but-theres-stilltime-to-act-124096

Miller CA, Iles A, Jones CF (2013) The social dimensions of energy transitions. Sci Cult 22:135-148. https://doi.org/10. 1080/09505431.2013.786989

Miller DD, Ota Y, Sumaila UR et al (2018) Adaptation strategies to climate change in marine systems. Glob Change Biol 24:e1-e14. https://doi.org/10.1111/gcb.13829

Moeller SD (1999) Compassion fatigue: how the media sell disease, famine, war, and death. Routledge, New York

Morgan MG, Fischhof FB et al (2002) Risk communication: a mental models approach. Cambridge University Press, Cambridge 
Morris A, Cushman F (2018) A common framework for theories of norm compliance. Soc Philos Policy 35:101-127. https://doi.org/10.1017/S0265052518000134

Moser SC (2010) Communicating climate change: history, challenges, process and future directions: communicating climate change. Wiley Interdiscip Rev Clim Change 1:31-53. https://doi.org/10.1002/wcc. 11

Munich RE (2017) A stormy year: TOPICS geo natural catastraphes 2017 report. Munich RE, Germany

Murakami H, Vecchi GA, Underwood S (2017) Increasing frequency of extremely severe cyclonic storms over the Arabian sea. Nat Clim Change 7:885-889. https://doi.org/ 10.1038/s41558-017-0008-6

Nash KL (2020) To achieve a sustainable blue future, progress assessments must include interdependencies between the sustainable development goals. One Earth 2:161-173

Nash KL, Alexander KA, Melbourne-Thomas J et al (2021) Developing achievable alternate futures for key challenges during the UN decade of ocean science for sustainable development. Rev Fish Biol Fish. https://doi.org/10.1007/ s11160-020-09629-5

Nilsson M, Griggs D, Visbeck M (2016) Map the interactions between sustainable development goals. Nature 534:320-322. https://doi.org/10.1038/534320a

Norris K, Anbarasu SC (2017) Clinical implications of cultural differences in factors influencing resilience following natural disaster: a narrative review. Int J Mass Emerg Disasters 35:38-60

Norris FH, Friedman MJ, Watson PJ et al (2002a) 60,000 Disaster victims speak: part I. An empirical review of the empirical literature, 1981-2001. Psychiatry Interpers Biol Process 65:207-239. https://doi.org/10.1521/psyc.65.3. 207.20173

Norris FH, Friedman MJ, Watson PJ (2002b) 60,000 Disaster victims speak: part II. Summary and implications of the disaster mental health research. Psychiatry Interpers Biol Process 65:240-260. https://doi.org/10.1521/psyc.65.3. 240.20169

Norström AV, Dannenberg A, McCarney G et al (2014) Three necessary conditions for establishing effective sustainable development goals in the anthropocene. Ecol Soc. https:// doi.org/10.5751/ES-06602-190308

Novaglio C, Bax N, Boschetti F et al (2021) Deep aspirations: towards a sustainable offshore blue economy. Rev Fish Biol Fish. https://doi.org/10.1007/s11160-020-09628-6

O'Gorman PA (2015) Precipitation extremes under climate change. Curr Clim Change Rep 1:49-59. https://doi.org/10. 1007/s40641-015-0009-3

Ogier E, Jennings S, Fowler A et al (2020) Responding to climate change: participatory evaluation of adaptation options for key marine fisheries in Australia's south east. Front Mar Sci. https://doi.org/10.3389/fmars.2020.00097

Oliver ECJ, Benthuysen JA, Bindoff NL et al (2017) The unprecedented 2015/16 Tasman Sea marine heatwave. Nat Commun 8:16101. https://doi.org/10.1038/ncomms16101

Oliver ECJ, Donat MG, Burrows MT et al (2018) Longer and more frequent marine heatwaves over the past century. Nat Commun 9:1324. https://doi.org/10.1038/s41467-01803732-9

Oliver ECJ, Burrows MT, Donat MG et al (2019) Projected marine heatwaves in the 21 st century and the potential for ecological impact. Front Mar Sci 6:734. https://doi.org/10. 3389/fmars.2019.00734

Pachauri RK, Mayer L (2015) Intergovernmental Panel on Climate Change (eds). Climate change 2014: synthesis report. Intergovernmental Panel on Climate Change, Geneva, Switzerland

Pecl GT, Araújo MB, Bell JD et al (2017) Biodiversity redistribution under climate change: impacts on ecosystems and human well-being. Science. https://doi.org/10.1126/ science.aai9214

Pecl GT, Ogier E, Jennings S et al (2019a) Autonomous adaptation to climate-driven change in marine biodiversity in a global marine hotspot. Ambio 48:1498-1515. https://doi. org/10.1007/s13280-019-01186-x

Pecl GT, Stuart-Smith J, Walsh P et al (2019b) Redmap Australia: challenges and successes with a large-scale citizen science-based approach to ecological monitoring and community engagement on climate change. Front Mar Sci 6:349. https://doi.org/10.3389/fmars.2019.00349

Pershing AJ et al. 2018. Oceans and Marine Resources, in Reidmiller DR, Avery CW, Easterling DR, Kunkel KE, Lewis KLM et al. eds., Impacts, Risks, and Adaptation in the United States: Fourth National Climate Assessment, Volume II. Washington, DC, USA: U.S. Global Change Research Program: 353-390

Pratchett MS, Cameron DS, Donelson J et al (2017) Effects of climate change on coral grouper (Plectropomus spp.) and possible adaptation options. Rev Fish Biol Fish 27:297-316. https://doi.org/10.1007/s11160-016-9455-9

Preston CJ (2013) Ethics and geoengineering: reviewing the moral issues raised by solar radiation management and carbon dioxide removal. Wires Clim Change 4:23-37. https://doi.org/10.1002/wcc. 198

Reif C, Osberghaus D (2020) Economic assessment of co-benefits of adaptation to climate change. In: Buchholz W, Markandya A, Rübbelke D, Vögele S (eds) Ancillary benefits of climate policy. Springer International Publishing, Cham, pp 197-212

Ripple WJ, Wolf C, Newsome TM, Barnard P \& Moomaw WR (2019) World scientists' warning of a climate emergency. BioScience:biz088

Robinson JB (1990) Futures under glass: a recipe for people who hate to predict. Futures 22:820-842. https://doi.org/10. 1016/0016-3287(90)90018-D

Rogelj J, Luderer G, Pietzcker RC et al (2015) Energy system transformations for limiting end-of-century warming to below $1.5^{\circ} \mathrm{C}$. Nat Clim Change 5:519-527. https://doi.org/ 10.1038/nclimate2572

Rose S, Jaramillo P, Small MJ et al (2012) Quantifying the hurricane risk to offshore wind turbines. Proc Natl Acad Sci 109:3247-3252. https://doi.org/10.1073/pnas. 1111769109

Rosenzweig C, Solecki W, Hammer SA, Mehrotra S (2010) Cities lead the way in climate-change action. Nature 467:909-911. https://doi.org/10.1038/467909a

Rousseau Y, Watson RA, Blanchard JL, Fulton EA (2019) Evolution of global marine fishing fleets and the response of fished resources. Proc Natl Acad Sci 116:12238-12243. https://doi.org/10.1073/pnas.1820344116 
Ryabinin V, Barbière J, Haugan P et al (2019) The UN decade of ocean science for sustainable development. Front Mar Sci 6:470. https://doi.org/10.3389/fmars.2019.00470

Scannell L, Gifford R (2013) Personally relevant climate change: the role of place attachment and local versus global message framing in engagement. Environ Behav 45:60-85. https://doi.org/10.1177/0013916511421196

Scheer D, Renn O (2014) Public perception of geoengineering and its consequences for public debate. Clim Change 125(3-4):305-318. https://doi.org/10.1007/s10584-014$1177-1$

Serrao-Neumann S, Davidson JL, Baldwin CL et al (2016) Marine governance to avoid tipping points: can we adapt the adaptability envelope? Mar Policy 65:56-67. https:// doi.org/10.1016/j.marpol.2015.12.007

Singh GG, Hilmi N, Bernhardt JR, Cisneros Montemayor AM, Cashion M, Ota Y, Acar S, Brown JM, Cottrell R, Djoundourian S, González-Espinosa PC, Lam V, Marshall N, Neumann B, Pascal N, Reygondeau G, Rocklv J, Safa A et al (2019) Climate impacts on the ocean are making the Sustainable Development Goals a target travelling away from us.Ban N (ed), People Nat 1(3):317-330

Smale DA, Wernberg T, Oliver ECJ et al (2019) Marine heatwaves threaten global biodiversity and the provision of ecosystem services. Nat Clim Change 9:306-312. https:// doi.org/10.1038/s41558-019-0412-1

Smith MD (2011) An ecological perspective on extreme climatic events: a synthetic definition and framework to guide future research: defining extreme climate events. J Ecol 99:656-663. https://doi.org/10.1111/j.1365-2745.2011. 01798.x

Smith DB, Haward M, McGee J et al (2020) Sharing our oceans fairly: improving international relations around ocean issues. Authorea. https://doi.org/10.22541/au.160441713. 30169042/v1

Sondak CFA, Ang PO, Beardall J et al (2017) Carbon dioxide mitigation potential of seaweed aquaculture beds (SABs). J Appl Phycol 29:2363-2373. https://doi.org/10.1007/ s10811-016-1022-1

Spijkers J, Boonstra WJ (2017) Environmental change and social conflict: the northeast atlantic mackerel dispute. Reg Environ Change 17:1835-1851. https://doi.org/10.1007/ s10113-017-1150-4

Spratt D, Dunlop I (2019) Existential climate-related security risk: a scenario report. Breakthrough - National Centre for Climate Restoration Melbourne, Australia.

Tauli-Corpuz V, Alcorn J, Molnar A et al (2020) Cornered by PAs: adopting rights-based approaches to enable cost-effective conservation and climate action. World Dev 130:104923. https://doi.org/10.1016/j.worlddev.2020. 104923

Tittensor DP, Beger M, Boerder K et al (2019) Integrating climate adaptation and biodiversity conservation in the global ocean. Sci Adv. https://doi.org/10.1126/sciadv.aay9969

Tompkins EL, Eakin H (2012) Managing private and public adaptation to climate change. Glob Environ Change 22:3-11. https://doi.org/10.1016/j.gloenvcha.2011.09.010

Tracy AM, Pielmeier ML, Yoshioka RM et al (2019) Increases and decreases in marine disease reports in an era of global change. Proc R Soc B Biol Sci 286:20191718. https://doi. org/10.1098/rspb.2019.1718
Ummenhofer CC, Meehl GA (2017) Extreme weather and climate events with ecological relevance: a review. Philos Trans R Soc B Biol Sci. https://doi.org/10.1098/rstb.2016. 0135

UNDRR (2015) Sendai Framework for Disaster Risk Reduction 2015 - 2030. United Nations Office for Disaster Risk Reduction, Switzerland

UNDRR (2019) Global Assessment Report on Disaster Risk Reduction. United Nations Office for Disaster Risk Reduction, Geneva, Switzerland

United Nations Environment Programme (2019) The emissions gap report 2019

United Nations (2015) Transforming Our World: The 2030 Agenda for Sustainable Development

Victor DG (2009) The politics of fossil-fuel subsidies. Glob Subsid Initiat GSI Int Inst Sustain Dev IISD Geneva Switz. https://doi.org/10.2139/ssrn.1520984

Walker T (2020) Listen to your people Scott Morrison: the bushfires demand a climate policy reboot. The Conversation

Walter RK, Hamilton RJ (2014) A cultural landscape approach to community-based conservation in Solomon Islands. Ecol Soc 19:41

Ward RD, Friess DA, Day RH, MacKenzie RA (2016) Impacts of climate change on mangrove ecosystems: a region by region overview. Ecosyst Health Sustain 2:e01211. https:// doi.org/10.1002/ehs2.1211

Ward D, Layton C, Bax N et al (2020) Safeguarding marine life: conservation of biodiversity and ecosystems. Rev Fish Biol Fish. https://doi.org/10.22541/au.160513367.73706234/v1

Webb LB, Hennessey K (2015) Climate Change In Australia: Projections for Selected Australian Cities. CSIRO and Bureau of Meteorology, Australia.

Wilburn King M (2019) How brain biases prevent climate action. BBC Futur. https://www.bbc.com/future/article/ 20190304-human-evolution-means-we-can-tackleclimate-change

Williams SE, Hobday AJ, Falconi L et al (2019) Research priorities for natural ecosystems in a changing global climate. Glob Change Biol. https://doi.org/10.1111/gcb.14856

Williamson P, Wallace DWR, Law CS et al (2012) Ocean fertilization for geoengineering: a review of effectiveness, environmental impacts and emerging governance. Process Saf Environ Prot 90:475-488. https://doi.org/10.1016/j. psep.2012.10.007

WMO (2019) United In Science: High-level synthesis report of latest climate science information convened by the Science Advisory Group of the UN Climate Action Summit (2019) World Meteorological Organization (WMO). Switzerland, Geneva

WOC, 2020. Sustainable Ocean Summit 2019 Summit Report: Executive Summary. World Ocean Council (WOC).

Worland J (2019) The Leaders of These Sinking Countries Are Fighting to Stop Climate Change. Here's What the Rest of the World Can Learn. TIME

Wylie L, Sutton-Grier AE, Moore A (2016) Keys to successful blue carbon projects: lessons learned from global case studies. Mar Policy 65:76-84. https://doi.org/10.1016/j. marpol.2015.12.020

Yamano H, Sugihara K, Nomura K (2011) Rapid poleward range expansion of tropical reef corals in response to rising 
sea surface temperatures: poleward range expansion of corals. Geophys Res Lett. https://doi.org/10.1029/ 2010GL046474

Yoshida K, Sugi M, Mizuta R et al (2017) Future changes in tropical cyclone activity in high-resolution large-ensemble simulations: future $\mathrm{TC}$ in large-ensemble simulations.
Geophys Res Lett 44:9910-9917. https://doi.org/10.1002/ 2017GL075058

Publisher's Note Springer Nature remains neutral with regard to jurisdictional claims in published maps and institutional affiliations. 